九州大学学術情報リポジトリ

Kyushu University Institutional Repository

\title{
A Revision of the Burmese Tertiary Turrids
}

Shuto, Tsugio

Faculty of Science, Kyushu University

https://doi.org/10.5109/1546094

出版情報：九州大學理學部紀要：Series D, Geology. 25 (2)，pp.115-157，1984-11-15. Faculty of Science, Kyushu University バージョン :

権利関係 : 
Mem. Fac. Sci., Kyushu Univ., Ser. D, Geol., Vol. XXV, No. 2, pp. 115-157, text-figs. 1-3, tables 1-3, November, 15, 1984

\title{
A Revision of the Burmese Tertiary Turrids
}

\author{
Tsugio SHUTO
}

\begin{abstract}
Burmese Tertiary turrids are taxonomically revised on the basis of reexamination of the type-specimens originally described by VREDENBURG (1921c). Among forty-two species, fifteen, one, four, one, thirteen, one and seven species are respectively included in Turriculinae, Clavatulinae, Turrinae, Borsoniinae, Clavinae, Conorbiinae and Mangeliinae. The Burmese Tertiary turrid fauna is characterized by richness of Turriculinae and Clavinae and paucity of Turrinae and particularly of Daphnellinae.

A good number of species have been proved to be in common between the Burmese and the Indonesian Tertiary and it has also been made clear that remarkable number of the Burmese turrid species have corresponding close allies in Indonesia. Burmese Tertiary turrids have verified their importance in the interregional correlation.
\end{abstract}

Several turrid species of Burmese Tertiary were described by NoETLING in his pioneer works on fossil molluses (1895 and 1901). His descriptions went into the detailed morphology of specimens, which are, however, generally poor in preservation. Twenty years later VREDENBURG gave valuable contributions to the subject with proper revision of NoETLING's monograph and descriptions of more than fourty species on the basis of new material. Then he also proposed a revised biostratigraphic divisions of the Burmese Tertiary.

The Burmese Tertiary turrids as a part of the molluscan fauna have been regarded as an important key for the comparative work of Southeast Asian turrids with the Indian and the Medditerranean ones because of an intermediate geographical position of Burma. Revision of those species under the current taxonomic ideas has been waited for long years for better comparison. Fortunately I had an opportunity to examine the type-specimens of forty-two species originally described mainly by VREDENBURG (1921 c and $1921 \mathrm{~d}$ ) and partly by NoztLING (1895 and 1901) at the Indian Museum during my visit to India, 1979. Observation of specimens was made under a hand glass and did not necessarily go into desirable details because a binocular was not available. Sketching was not performed with the aid of an optic drawing aparatus and in consequence accuracy of drawing in this report is insufficient comparing with my serial papers on turrids. This report contains notes on turrid taxonomy of those species and a brief note on biostratigraphic significance of the Burmese Tertiary turrids.

I wish here to express my sincere thanks to Dr. M. V. A. SASTRY, Director of Palaeontology and Stratigraphy Division, Geological Survey of India, for his generous help to make me access to the turrid type-specimens. Thanks are also

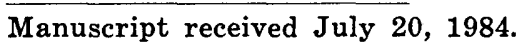


extended to Mrs. Krishna Ray ChaUdHURI for her kind assistance in preparing necessary material.

\section{Descriptions of species}

Family Turridae SwaInson, 1840

Subfamily Turriculinae PowelL, 1942

genus Turricula SchUMACHER, 1817

type-species: Turricula flammea ScHUMACHER, monotypy

synonym: Surcula H. and A. AdAMS, 1853

Turricula sethuramae (VREDENBURG)

Text-fig. 1, No. 5

1921, Surcula sethuramae VRedenburG, Rec. Geol. Surv. Inddia, Vol. 53, Pt. 2, p. 88 , pl. 12 , f. 3 .

1969, Turricula sethuramae, Powerl, Indo-Pacific Moll., Vol. 2, No. 10, p. 240, pl. 199 , fs. 2 and 3.

Material.-GSI Type No. 12433 from the Upper Miocene of Dalabe. Preservation is excellent. $\mathrm{H}=13.1 \mathrm{~mm}, \mathrm{D}=4.9 \mathrm{~mm}$. Protoconch ca. 3 volutions, teleoconch 6.5 whorls.

Descriptive remarks.-The holotype is featured by its Gemmula-type profile with high spire, long base and gemmulate periphery. However, its protoconch is conical and smooth throughout and the anal sinus occupies the shoulder sulcus with a broad apex at about the middle of the sulcus which is provided with fine spiral lines. Subsutural cord is prominent and simple. Its gemmulate peripheral hoop of spire-whorls is close to the lower suture. The pyriform aperture has a distinct posterior gutter and is contracted anteriorly to a long and terminally truncated canal. Two primary spiral lirae just below the periphery on the body whorl are coarsely crenulate.

Comparison.-Powell (1969, p. 240) assigned this species to Turricula SCHUMACHER, 1817 and regarded it as a dwarf form of Turricula nelliae spurius (HEDLEY). T. nelliae spurius, living in South and Southeast Asian waters, is really a close ally to the present species, but the latter is yet separated from the former in having prominent, smooth and simple subsutural cord, more oblique crenules on peripheral cord and more distinct columellar calus than the former.

VREDENBURG compared this species in his original description with Pleurotoma tuberculata GraY, which is, according to Powell (op. cit.), a synonym of T. nelliae. "Surcula sethuramae" is, however unlike T. nelliae by it heavier subsutural cord and strongly granulate basal spiral lirae.

They comprise a particular group of Turricula together with Turricula urnula (THIELE) from off the mouth of Congo River (1925, p. 225, pl. 36, f. 14), T. gemmulaeformis (THIELE) from off Sumatra (op. cit., p. 336, pl. 36, f. 20), T. "nodifera LAMARCK var." of MARTin from the Pliocene of Java (1883, p. 61, pl. 4, f. 61), T. saubrigiana (Grateloup) from the Upper Miocene of Aquitania (in Cossmann and PEYrot, 1931, p. 81, pl. 6, fs. 21, 26 and 27), T. asperulata 
(LAMARCK) from the Middle Miocene of Aquitania (in Cossmann and PeYrot, op. cit. p. 70, pl. 5, fs. 3, 5, 7, and pl. 6, f. 24), etc. This group was flourished in the Tethyan waters from South Europe through Southeast Asia.

\title{
T. navarchus thangaensis (VREDENBURG)
}

Text-fig. 1 , Nos. 10 and 11

1921, Surcula thangaensis VRedendurg, Rec. Geol. Surv. India, Vol. 53, Pt. 2, p. 88 , pl. 12 , f. 5 .

1969, Turricula thangaensis, PowelL, Indo-Pacific Moll., Vol. 2, No. 10, p. 241, pl. 199 , f. 1.

Material.-GSI Type No. 12435 from the Upper Miocene of Thanga. Apical and basal parts broken off. Six whorls preserved. Length of spire ca $9 \mathrm{~mm}$.

Descriptive remarks. - The specimen has a turreted spire of about $9 \mathrm{~mm}$ high consisting of six whorls, which are differentiated into three parts, a sharply crenulate subsutural band, infrasutural sulcus and costate lateral part below peripheral angulation. Infrasutural sulcus is not wide and is bounded above and below respectively by a narrow but defined groove and is provided with low cord between. Slightly prosoclinally elongate crenules on subsutural band and opisthocline costae on lateral side are connected by fine opisthocyrtly curved threads and constitute axial sculpture. Anal sinus is moderately deep v-shaped with its apex on the infrasutural sulcus. Its forwardly extending upper arm is abruptly flexed upward immediately after merging with subsutural band and the lower arm is gently curved downward after moderate forward extension. Canal unknown. Columellar lip is straight and long.

Comparison.-The present species does not quite conform with any known species in its morphology, but it is closest to Turricula navarchus (MELvILL and STANDEN) from the Gulf Oman (1903, p. 310, pl. 21, f. 15). Really, morphological feature of two species is quite identical until juvenile stage to have a narrow anal sulcus between crenulate subsutural band and obliquely costate lateral band. Thereafter, however, lateral band rather abruptly loses its costae and becomes roundly convex on $T$. navarchus, while $T$. thangaensis keeps the above mentioned feature throughout growth-stages. T. navarchus is undoubtedly regarded as an offspring of T. thangaensis as PowELL pointed out.

It also shows some similarity to $T$. obliquicosta (v. MARTENS) from West Sumatran Sea (1901 in 1903, p. 80, pl. 2, f. 1), but is readily distinguished from the latter in having stronger subsutural band.

\author{
subgenus Nangulanica SHUTO, 1980 \\ type-species: Surcula hillegondae MARTIN, (o.d.) \\ T. (Nangulanica) birmanica (VREDENBURG) \\ Text-fig. 2, Nos. 21 and 22
}

1921, Drillia (Crassispira) birmanica Vredenburg, Rec. Geol. Surv. India, Vol. 53, Pt. 2, p. 121, pl. 14, f. 6.

Material.-GSI Type No. 12462 from the Miocene of Tittabwe, Burma. 
Labrum not preserved. Nuclear part of the protoconch is also missing. $H=$ ca $12.0 \mathrm{~mm}, \mathrm{D}=3.4+\mathrm{mm}$. Protoconch ca 3.5 volutions, teleoconch 5.8 whorls.

Remarks and comparison.-Protoconch is conical consisting of roundly convex volutions. They are smooth except for the last half volution which is provided with opisthocyrtly curved thin axials. Comparing with typical Crassispira SWAINSON, 1840, the present species has higher protoconch with more numerous volutions, more definitely contracted base, weaker axial ribs confined to lateral part of each whorl, weaker basal fasciole, wider spirals separated one another by narrow grooves and narrower subsutural cord. Accordingly it does not quite agree with Crassispira, although the original author referred it to that genus.

The present species is closely similar to Surcula hillegondae MarTiN (1914, p. 116, pl. 1, f. 16 and 17) from the Middle Eocene of Java and is just distinguished from the latter in having narrower subsutural cord and finer, closer and less curved axials than the latter. The latter was designated as the type species of Nangulanica SHUTO, 1980 with its characteristic sculpture, protoconch and anal sinus. The present species is reasonably referred to Nangulanica.

genus Antimelatoma PoweLL, 1942

type-species: Drillia maorum SмiтH, (o. d.)

\section{Antimelatoma? buddhaica (VREDENBURG)}

Text-fig. 1, Nos. 33 and 34

1921, Drillia (Brachytoma) buddhaica VRedenburg, Rec. Geol. Surv. India, Vol. 53, Pt. 2, p. 115 , pl. 13, f. 7.

Material.-GSI Type No. 12453 from the Miocene of Myaukmigon, Burma. Body whorl and 3.5 spire-whorls are preserved. $\mathrm{H}=20.2+\mathrm{mm}, \mathrm{D}=7.0 \mathrm{~mm}$.

Remarks and comparison.-The present species is featured by such characteristics as fusiform profile, fold-like axials, elongate aperture with long, wide and terminally truncated canal, obscure callus on inner lip, moderately deep vshaped anal sinus on shoulder depression and moderately developed basal fasciole. It is evidently allied to the generic group of Turricula SchuMACHER, 1817 and Comitas Finlay, 1926 and almost conforms with Antimelatoma Powell, 1942 except for the basal fasciol. However, reference is not concrete because type specimen of Drillia (Brachytoma) buddhaica lacks the apical part. Morphological feature of the basal part of the present species, including fasciole and wide canal, seems to claim its taxonomic relation to Crassispira SWAINSON, 1840, Inquisitor HEDLEY, 1918 and some other clavid genera, but the former is neither solidly nor crudely built and is devoid of the prominent parietal callus. Under such circumstance mentioned above, the present species is tentatively included in Antimelatoma, which hitherto has been known from New Zealand and south Australia.

Fold-like axials are seven per one whorl and restricted to the peripheral part. They are nodulous and erect on spire whorls and remarkable weakened on the body whorl. Spiral ornament consists of the primaries, secondaries and tertiaries and they are remarkably different in size to one another on the early 
whorls but the difference becomes obsolete on later whorls, which are covered by fine and minute lines.

genus Nihonia MACNEIL, 1960

type-species: Nihonia shimajiriensis MACNEIL, (o. d.)

Nihonia? birmanica (VREDENBURG)

Text-fig. 1, No. 21

1921, Surcula birmanica Vredenburg, Rec. Geol. Surv. India, Vol. 53, Pt. 2, p. 90, pl. 12 , f. 4.

1969, ? Nihonia birmanica, Powell, Indo-Pacific Moll. Vol. 2, No. 10, p. 334, pl. 255 , f. 7 .

Material.-GSI Type No. 12434. Miocene of Tetma, Burma. The holotype is a broken and worn specimen consisting of three and a half whorls. Both the apical and basal parts are not preserved.

Descriptive remarks.-Profile of the preserved whorls suggests a shell-form similar to Nihonia MACNEIL, 1960, or slender forms of Turricula SchuMACHER, 1817. The anal sinus of the present specimen is moderately shallow with its blunt apex at the middle of infrasutural shallow depression and the lower arm of the sinus is forwardly swinging. Blunt peripheral angulation is at the middle of each whorl. Surface between the lower suture and the peripheral angulation is provided with alternation of primary cords and secondary lines. A few spiral threads and lines are also discernible below the upper suture. Middle part of the infrasutural depression is free from spirals.

Comparison.-Exact systematic position at the generic level of the present species is not clear because of lack of information about both aperture and protoconch. Observed characteristics of the preserved whorls, however, suggest a closer relation to Nihonia MACNEIL, 1960 than any other genera. The most critical reason that I hesitate to concretely refer it to Nihonia is remarkably shallower anal sinus of the present species than known species of Nihonia.

It is somewhat similar to N. santosi SHuTo (1969, p. 186, pl. 19, f. 18, 19 and 21) from the Uppermost Miocene of Panay Island, the Philippines, but the former has decidedly shallower anal sinus than the latter. The original author compared the present species with Surcula sismondae (BELlaRd and MICHELOTTI, 1840 in BellaRdi, 1877, p. 81, pl. 2, f. 29) from the Upper Miocene of Piedmont, Italy, which must be included in Nihonia judging from the general facies. $N$. birmanica and sismondae are almost identical to each other in sculpture and anal sinus, except for slightly stronger subsutural lirae and larger pleural angle on the present species than on sismondae.

Recently BEETS described a new species of Nihonia, N. witkampi, from the Preangerian lower Songkuliran Marl of Kari Orang, Kalimantan (1983, p. 54, pl. 4 , fs. 6 and 7 ). On that occasion he recognized a close similarity between his new species and $N$. birmanica. They are really so closely conformable with each other that they may be regarded as conspecific in spite of a slight difference in the anal sinus which is just shallower with the apex at slightly more abapical portion in $N$. birmanica than in N. witkampi. 
genus Pleurofusia de Gregorio, 1890

type-species: Pleurotoma (Pleurofusia) longirostropis

de GrEgorio, (o. d.)

synonyms: Tropisurcula CASEY, 1904 and Tropidosurcula Cossmann, 1906

\section{Pleurofusia fusus VREDENBURG}

Text-fig. 1, Nos. 12 and 13

1921, Surcula (Pleurofusia) fusus Vredenburg, Rec. Geol. Surv. India, Vol. 53, Pt. 2, p. 90, pl. 12, f. 6.

1969, ? Pleurofusia fusus, Poweld, Indo-Pacific Moll., Vol. 2, No. 10, p. 305, pl. 238, f. 6.

Material.-GSI Type No. 12436 from the Miocene of Payagyigon, Burma. Apical and basal parts are broken off on both specimens. specimen a: $\mathrm{H}=40.9+$ $\mathrm{mm}, \mathrm{D}=17.7 \mathrm{~mm}, 6$ whorls. specimen $\mathrm{b}: \mathrm{H}=35.1+\mathrm{mm}, \mathrm{D}=15.0 \mathrm{~mm}, 5$ whorls.

Remarks.-Shell is typically fusiform. Plicated axial ribs are erect and defined at their base by sharp angle. Interspaces are as wide as ribs and are provided with distinct growthlines. Shoulder angle is distinct. Anal sinus is shallow with its broad apex on the infrasutural shoulder slope, which is moderately narrow and free from spirals. The lower arm of sinus is broadly swinging forwardly. Although protoconch is not known, morphological feature of the teleoconch of the present species suggests its systematic position in the genus Pleurofusia de GrEgorio, 1890 on the basis of Fusinus-like profile and turriculine anal sinus. Among species of the genus, the present species is very characteristic by its wavy and finely dotted spiral thread which separate basal slope from snout.

\section{P. phasma VREDENBURG \\ Text-fig. 1, No. 6}

1921, Surcula (Pleurofusia) phasma Vredenburg, Rec. Geol. Surv. India, Vol. 53, Pt. 2 , p. 93 , pl. 12, fs. $7 \mathrm{a}$ and b.

1969, Pleurofusia phasma, Powell, Indo-Pacific Moll. Vol. 2, No. 10, p. 304, pl. 238 , fs. 3 and 4 .

Material.-GSI Type No. 12437 from the Upper Miocene of Dalabe, Kyaungon district, Burma. $\mathrm{H}=26.1 \mathrm{~mm}, \mathrm{D}=7.2 \mathrm{~mm}$. Six and a half whorls preserved.

Remarks.-Pattern of sculpture on the later whorls are quite similar between the present species and $P$. iravadica, but development of spiral lirae on early whorls is clearly different from each other. That is to say, sharp peripheral angulation coinsides with the second upper one of four lirae on $P$. phasma instead the uppermost one of three lirae on $P$. iravadica. They may represent respectively different lineages.

Fusiturricula phasma (VREDENBURG) var. of DEY (1962, p. 96, pl. 8, f. 8) from the Quilon Miocene of South India has narrower and less defined shoulder sulcus than $P$. phasma. 


\section{P. feddeni iravadica VREDENBURG}

Text-fig. 1, Nos. 17 and 18

1921, Surcula (Pleurofusia) iravadica VREDenburG, Rec. Geol. Surv. India, Vol. 53, Pt. 2, p. 90, pl. 12, f. 9.

1969, Pleurofusia iravadica, Powell, Indo-Pacific Moll. Vol. 2, No. 10, p. 304, pl. 238, fs. 1 and 2.

Material.-GSI Type No. 12439 from the Upper Miocene of Dalabe, Kyaungon distict, Burma. Protoconch broken off, otherwise almost perfect. $\mathrm{H}=31.2+\mathrm{mm}$, $\mathrm{D}=9.3 \mathrm{~mm}$.

Description.-Shell is elongately fusiform with distinct basal contraction. Fold-like axial ribs are six respectively on the first, antipenultimate, penultimate and body whorls. Primary spirals are distinct and four on the preserved first whorl; one subsutural and three on the lateral surface. Interspace between the upper two spirals is a concave anal sulcus and much wider than others, which are almost equal in breadth. Secondary threads and tertiary fine lines are respectively introduced on the lateral side and infrasutural sulcus of the preserved third whorl. Spirals become weaker through growth stages. Axials are strong on lateral side, abruptly disappear above peripheral angulation and are faded out on the basal slope. Anal sinus wholly occupies the sulcus and remarkably deep with its apex at the middle of the sulcus. The upper arm of sinus merges with the upper suture by an angle of about 30 degrees and the lower arm is swinging forwardly over peripheral angulation and then gradually curved downward. Subsutural lira is not strong. Long and straight snout is covered with fine alternation of secondary and tertiary spiral lines. Canal is long, wide and straight. Callus of inner lip is not thick.

Comparison.-The present species is included in Pleurofusia on the basis of the above noted characteristics. The original author compared the present species with Surcula (Pleurofusia) feddeni NoETLING from the lower Miocene of Minbu, Burma and they really show similar morphology, but, according to the original author, they are distinguishable from each other by difference in their ontogenetic development of sculpture. While the latter is featured by ontogenetically strengthened spiral sculpture, the former holds the same strength of spirals throughout growth stages. Besides, secondary and tertiary spirals are more distinct on $P$. iravadica. The above mentioned differences are, however, very slight and they can not be reasonably separated at species level.

It closely resembles Pleurofusia phasma VREDENBURG, but is distinguished from the latter which has slenderer profile and somewhat shallower anal sinus and, besides, they are different in the developmental frame work of spiral sculpture as mentioned before.

Pleurotoma (?Drillia) sedanensis HAANSTRA and SPIKER (1932, p. 1099, pl. f. 8 and 9) from the Lower Middle Miocene of Rembang, Java is referred to Pleurofusia and closely similar to $P$. iravadica. The former is just distinguished from the latter in having less crasping suture. 


\section{P. feddeni feddeni (NoETLING)}

1895. Fasciolaria feddeni Noetzing, Mem. Geol. Surv. India, Vol. 27, p. 35, pl. 8, fs. 4 and 4 a.

1901, Surcula feddeni Noetring, Palaeontogr. Indica, N. S., Vol. 1, p. 346, pl. 22, fs. 22, 22a, 24 and $24 a$ (non 23 and 23a).

1921, Surcula feddeni, VRedenburg, Rec. Geol. Surv. India, Vol. 51, pt. 3, p. 282. 1921, Surcula (Pleurofusia) scala var. VRedenburg, ibid. Vol. 53, Pt. 2, pl. 12, f. 10 .

1969, Pleurofusia feddeni, Powell, Indo-Pacific Moll., Vol. 2, No. 10, p. 303, pl. 237 , fs. 1 and 3.

Remarks.--According to the original description and figure, Surcula feddeni (NoETLING) is featured by such characteristics as distinct peripheral angulation, shallow and almost smooth shoulder sulcus, remarkably convex lateral side, pronounced basal contraction and prominent axial ribs weakened but still extending over shoulder sulcus. NoEtring (1901, p. 346) included a specimen, once referred to Pleurotoma interrupta LAMARCK $(1895$, p. 41, pl. 10, f. 1, la [non 21]) in S. feddeni (1901, p. 346), but the specimen must be reasonably separated from $S$. feddeni, because the former has notably weaker basal contraction and less convex lateral side.

Later, VREDENBURG distinguished a specimen among NoETLING's material (1901, pl. 22, f. 24) and gave the specific name, S. scala (1912 a, p. 282). That specimen has weak spirals on the shoulder sulcus, otherwise it quite conforms to the typical form of $S$. feddeni which ranges in Lower Miocene. VREDENBurG, in his succeeding paper (1921 c, pl. 12, f. 8), gave the figure of a Middle Miocene specimen from Tittabwe as Surcula (Pleurofusia) scala n. sp. without description. This specimen is, however, quite different from $S$. scala VREDENBURG (1921 a) =S. feddeni (NoETLING, 1901, pl. 22, f. 24 [non 22, 231]). On that occasion, VREDENBURG also gave a figure of $S$. (Pleurofusia) scala var. (1921 c, pl. 12 , f. 10), which is by no means different from above specimen (NoETLing, 1901, pl. 22, f. 24).

It resembles Pleurotoma (Surcula) avia Bellardi from the Middle Miocene of Piedmont, Italy (1877, p. 69, pl. 2, f. 18), but is distinguished from the latter in being provided with less expanded shoulder and much weaker secondary spirals.

subgenus Neopleurofusia nov. type-species._-Pleurofusia (Neopleurofusia) scala VREDENBURG, subgen. nov.

Diagnosis.-Shell small, fusiform with sharply angulate whorls. One angulation at upper two-fifth on spire whorls and two angulations, peripheral and basal ones, on body whorl. Sculpture of bold axial folds overriden by distinct spiral lirae on lateral surface. Axials disappear immediately below basal angulation and is abruptly faded away above peripheral angulation. Basal slope and snout have crowded weak spiral threads. Wide and concave shoulder slope is devoid of spirals, but is provided with growth lines, which show asymmetri- 
cally v-shaped anal sinus with its apex somewhat above middle of shoulder slope. Aperture is the same as that of Pleurofusis (s.s.).

Comparison.-The present taxon is distinguished from Pleurofusia (s.s.) in having bold axial folds limited between very sharp peripheral and basal angulations and having smoother shoulder slope. In these respects, the present taxon represents an intermediate form between Plurofusia (s.s.) and Cosmasyrinx MARWICK, 1931, but somewhat closer to Pleurofusia (s.s.). C. tereumera MARWICK from the Middle Miocene of New Zealand (1931, p. 139, f. 259) is again just an intermediate form between the present taxon and typical Cosmasyrinx. Accordingly it is a problem where the boundary is set between Cosmasyrinx and Neopleurofusia. I am inclined, however, to include $C$. tereumera in Neopleurofusia, because the former has distinct axial ribs which extend beyond the peripheral angulation to the shoulder sulcus.

Pleurofusia (Neopleurofusia) scala VREDENBURG subgen. nov.

Text-fig. 1, Nos. 7-9

1921, Surcula (Pleurofusia) scala VREDENBUrg, Rec. Geol. Surv. India, Vol. 53, Pt. 2, pl. 12, f. 8.

1969, Pleurofusia scala, Powell, Indo-Pacific Moll. Vol. 2, No. 10, p. 306, pl. 238, f. 5 .

Material.-GSI Type No. 12438 from the of Tittabwe, Burma. Both apical and basal parts broken off. Five whorls preserved. $H=32.1 \mathrm{~mm}, \mathrm{D}=19.1 \mathrm{~mm}$.

Diagnosis. - The same as the subgeneric diagnosis.

Description.-Shell is thin, moderately large and fusiform. Body whorl is divided into three parts by sharp peripheral and basal angulations. Subsutural part is gently sloped and somewhat concave immediately below suture and is devoid of any spiral sculpture. Lateral side between two angulations is almost straight and receding in profile and is covered by primary, secondary and tertiary spirals, of which the primaries and secondaries are particularly strong. Fold-like prominent axial ribs are developed on the lateral side and they form rounded nodes on the peripheral angulation above which the ribs are extended but abruptly weakened. Axial ribs disappear immediately below the basal angulation. Base is remarkably contracted and then continued to the straight snout. Anal sinus fully occupies the shoulder slope with its apex closer to suture than to periphery. Growthlines are raised on the interspaces of axial ribs and weak on both the shoulder slope and basal surface. In the apical view, the periphery shows a cycloid design. Aperture is rhomboid and contracted at the lower part.

Preserved first whorl $(\mathrm{D}=3.3 \mathrm{~mm})$ is trapezoid in profile with distinct peripheral angulation, above which is moderately sloped, smooth and hardly concave shoulder slope. Below the peripheral angulation is the slightly receding lateral side which is thickly covered by three primary spirals and somewhat weaker secondary ones.

Comparison.-The present species represents an intermediate form between Pleurofusia de Gregorio, 1890 and Cosmasyrinx MARWICK, 1931 and is someshat similar to C. tereumera MARWICK. The former is, however, distinguished from 
the latter in having more prominent axial ribs of less number and more pronounced basal angulation than the latter.

subgenus Pseudofusia SHuto, 1969

type-species: Pleurofusia (Pseudofusia) dinglensis SHUTo, (o.d.)

\section{Pleurofusia (Pseudofusia?) yabei (VREDENBURG)}

Text-fig. 1, Nos. $14-16$

1921, Drillia (Brachytoma) yabei VRedenburg, Rec. Geol. Surv. India, Vol. 53, Pt. 2, p. 113, pl. 13, fs. 3a and b.

Material.-GSI Type No. 12449 from the Miocene of Thanga, Burma. Almost perfectly preserved. $\mathrm{H}=19.5 \mathrm{~mm}, \mathrm{D}=6.7 \mathrm{~mm}$.

Descriptive remarks and comparison.-The specimen shows following characteristics: moderately concave infrasutural shoulder slope; long and straight snout below the strong basal contracation; nodose prominent axial folds abruptly faded immediately above shoulder angulation and below blunt basal angulation; long, rather wide and unnotched canal; prominent parietal entering callus pad, moderately deep v-shaped anal sinus occupying shoulder slope, distinct and regular spiral threads, smooth and globose protoconch consisting of two and a half volutions. These characteristic features indicate that the present species is included in Pleurofusia and probably in subgenus Pseudofusia SHuto, 1969. The present species resembles in the adult facies Pleurofusia (Pseudofusia) dinglensis SHUTO from the Uppermost Miocene of Panay, the Philippines (1969, p. 189, pl. 21, f. 11 and 18), but is distinguished from the latter in having one half smaller shell, globose paucispiral protoconch instead of tall conical one, weaker parietal callus pad and smooth anal band.

genus Paradrillia MaKiYama, 1940

type-species: Drillia dainichiensis YokоYama, (o.d.)

\section{Paradrillia? iravadica (VREDENBURG)}

Text-fig. 2, No. 12

1921, Pleurotoma (Hemipleurotoma) humilis BEYRICH var. iravadica VREDENBURG. Rec. Geol. Surv. India, Vol. 53, Pt. 2, p. 98, pl. 12, f. 13.

Material.-GSI Type No. 12443 from the Miocene of Payagyigon, Burma. Three and a half whorls preserved.

Descriptive remarks. - The present unsuitably preserved specimen shows a Paradrillia-like feature in the profile of shell and sculpture. Whorls are provided with a strong and crenulated subsutural lira, moderately concave and smooth infrasutural sulcus and cancellated lateral side below the peripheral angulation. Basal contraction is distinct. Axials are rather thin and vertical separated from one another by wider interspaces and are regularly spaced on spire-whorls but become irregular on body whorl. Anal sinus is moderately shallow with its apex at about middle of the subsutral sulcus. Spiral sculpture consists of four primary lirae and a few fine secondary lines on the lateral side 
of spire whorls. The uppermost lira, which coincides with the peripheral angulation, is stronger than others.

Comparison.-It is similar in morphology to Paradrillia MaKIYAMA, 1926 and Vexitomina Powell, 1942, but its identity is not verified because the present specimen does not take with operculum, which is a sole basis for separation of above two genera. Here, it is tentatively placed in Paradrillia.

The original author compared the present taxon with Pleurotoma humilis BEYRICH in KOENEN (1890). KOENEN illustrated by this name two turrine forms $(1890$, pl. 28 , fs. 5 and 6$)$ which are remarkably different from each other in profile and basic pattern of sculpture and must be separated, at least, at species level. The present taxon is quite different from either of above mentioned forms of $P$. humilis in having the apex of anal sinus at the middle part of the shoulder sulcus instead on peripheral carina in P. humilis.

genus Eosurcula CASEY, 1904

type-species: Pleurotoma moorei GABB, (s.d. by VoKes, 1939)

Eosurcula irravadica (NOETLING)

Text-fig. 1, No. 26

1895, Pleurotoma (Cryptoconus) irravadica Noetling, Mem. Geol. Surv. India, Vol. 27, Pt. 1, p. 41, pl. 9, f. 6.

1901, Genotia irravadica, Noeturng, Palaeont. Indica, N. S., Vol. 1, Pt. 3, p. 347, pl. 22 , fs. 25 and 26.

1921, Genotia irravadica, VRedendurg, Rec. Geol. Surv. India, Vol. 53, Pt. 2, pl. 131, pl. 15, fs. $3 a$ and b.

Material.-GSI Type No. 12333 from the Sitsayan Stage, Mindegyi, Burma. Apical part and anterior end of canal are broken off. Six whorls preserved. $\mathrm{H}=$ ca $39 \mathrm{~mm}, \mathrm{D}=\mathbf{9} .1 \mathrm{~mm}$.

Descriptive remarks.-The present species is featured by the following characteristics. Shell is slender fusiform consisting of numerous high whorls with moderately developed subsutural band, which is superimposed by a distinct lira on the first to fourth whorl. Somewhat smaller lira is added above the foregoing one on the penultimate whorl. Below the subsutural band is a wide shoulder slope, of which the upper one-fourth is shallowly concave and the remainder part is very slightly convex and is provided with several minute spiral lines. Vertical lateral side has regularly spaced four or five spiral lirae crossed by weaker growth threads or lirae on the spire-whorls. The border area between the shoulder slope and lateral side forms a blunt angulation. Spiral lirae on the gradually tapered basal slope are weaker than those on the lateral surface. Primary spiral lirae on the body whorl are intercalated by a secondary thread in each interspace. Axials are 23 on the second and third whorls and are gradually increased to $26-27$ on the penultimate whorl. A thin secondary axial lira is intercalated in every 4-5 interspaces of the lower part of the later whorls. Intersections of axials and spirals are weakly granular. Anal sinus is moderately shallow v-shaped. Its apex is at the middle of spirally striated part of shoulder slope and forms elongate crenulation. The lower arm of sinus does 


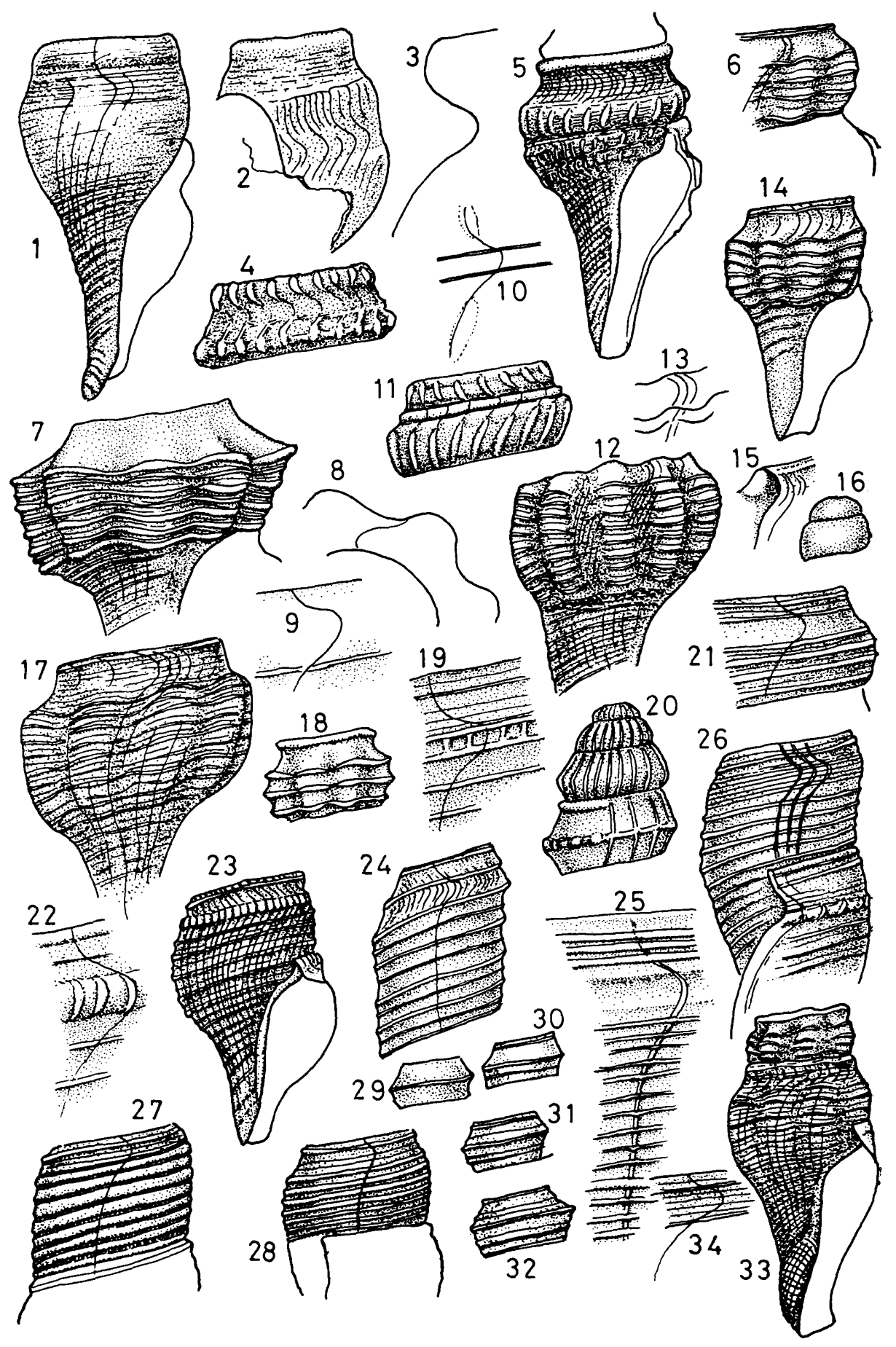


not swing forward but curves vertically. Aperture is very long and narrow with parallel lips. Canal is very long and its terminal feature is not observed because of fracture. No apertural process.

Comparison.-The present species is close to Apiotoma Cossman, 1889 and Eosurcula CASEY, 1904. While Eosurcula has slenderer shell with sculpture predominated by spirals over axials than Apiotoma, the protoconch of the former is polyspiral and conical one instead of globose paucispiral one of the latter. In the case of the present species, only teleoconch is simply compared because lack of information about protoconch of the present species. Comparison shows that the present species stands at an intermediate position between the two genera but somewhat closer to Eosurcula. It is very difficult to exactly compare the present specimen with NoETLING's original one, to which I have not been made access, because descriptions and figures of Pleurotoma (Cryptoconus) irravadica (1895) and Genotia irravadica (1901) by the original author are not preferably clear. As far as the literal comparison is concerned, VREDENBURG's specimen seems somewhat different from NoETLING's specimens particularly in the characteristics of shoulder slope and sculptural pattern. However, present

\section{Text-fig. 1 Burmese Tertiary turrids}

1-4. Perrona birmanica VRedenburg. 1,3 and 4, GSI Type 12432, from Myauktin; 2, GSI Type 12431 from Thanga.

5. Turricula sethuramae (VREDENBURG). GSI Type 12433 from Dalabe.

6. Pleurofusia phasma (VREDENBURG). GSI Type 12437 from Kyaungon.

7-9. Pleurofusia (Neopleurofusia) scala VREDENBURG. GSI Type 12438 from Tittabwe.

10-11. Turricula navarchus thangaensis VREDENBURG. GSI Type 12435 from Thanga.

12-13. Pleurofusia fusus VRedendurg. GSI Type 12436 from Payagyigon.

14-16. P. (Pseudofusia) yabei (VREDENBURG). GSI Type 12449 from Thanga.

17-18. P. feddeni iravadica VREDENBURG. GSI Type 12439 from Kyaungon.

19. Ptychosyrinx birmanicus (VREDENBURG). GSI Type 12442 from Myaukmigon.

20. Gemmula (Paragemmula) thyrsus VReDenburG. GSI Type 12441 from Kyaungon.

21. Nihonia ? birmanica (VRedenbURG). GSI Type 12434 from Tetma.

22. Epalxis singuensis (VREDENBURG). GSI Type 12446 from Singu.

23. Xenuroturris (Reticuloturris) iris (VREDENBURG). GSI Type 12444 from Thanga.

24. Eosurcula garrowi (VREDenBURG). GSI Type 12332 from Thetkegyin.

25. Genota ? singuensis (VREDENBURG). GSI Type 12331 from Singu.

26. Eosurcula irravadica (NoEtLING). GSI Type 12333 from Mindegyi.

27-32. E. birmanica (VREDENBURG). 27, GSI Type 12335 from Thetkegyin; 28-32, Type 12334 a from Kyaukkwet Chaung. 29, 30, 31 and 32 are respectively preserved first, second, third and fourth whorl.

33-34. Antimelatoma ? buddhaica (VREDENBURG). GSI Type 12453 from Myaukmigon. 
specimen is tentatively noted here under the name given by NoETLING. VREDenBURG noted the affinity of the present species to Genota craverii BELLARDI (1877, p. 86, pl. 3 , fs. 3 and 4 ) from the Tortonian of Piedmont, but they are readily distinguished from each other because the latter is provided with definitely sharper peripheral angulation and defined axials even on the shoulder slope.

\section{E. garrowi (VREDENBURG) \\ Text-fig. 1, No. 24}

1921, Genotia garrowi Vredenburg, Rec. Geol. Surv. India, Vol. 53, Pt. 2, p. 132, pl. 15 , f. 2 .

Materials.-GSI Type No. 12332 from the Yaw stage of Thetkegyin, Burma. Only two whorls preserved.

Remarks.-Whorl is higher than wide, distinctly angulate at upper onefourth height and sculptured by regular spiral lirae and distinct growthlines. Spirals consists of subsutural lira, one on angulation, one between them and four pairs of alternation of primary lirae and somewhat smaller secondary threads on lateral side. An interspace is wider than the next lower one. Anal sinus indicated by growthlines is moderately deep v-shape with its apex between the angulation and the next upper lira. Its upper arm merges to the upper suture at about 60 degrees and lower arm is bent downward vertically on and around the shoulder angulation.

It is referred to Eosurcula by its characteristic morphology, although apical part and aperture are not preserved.

Eosurcula deningeri (MARTIN) from the Middle Eocene of Java (1914, p. 113 , pl. 1, f. 10) is the closest ally to the present species, yet the latter is distinguished from the former in having higher whorl with one couple more alternating spirals and lower position of the apex of anal sinus on shoulder slope.

\section{E. birmanica (VREDENBURG)}

Text-fig. 1, Nos. 27-32

1921, Genotia birmanica VRedenburg, Rec. Geol. Surv. India, Vol. 53, Pt. 2, p. 132 , pl. 15 , fs. 4 and 5 .

Material.-GSI Type No. 12334 a (pl. 15, f. 4) and b from the Yaw Stage of Kyaukkwet Chaung and No. 12335 (pl. 15, f. 5) from the same stage as above of Thetkgyin, Burma. No. $12334 \mathrm{a} \mathrm{H}=$ ca $14.5 \mathrm{~mm}, 5.5$ whorls preserved. No $12334 \mathrm{~b} \mathrm{H}=$ ca $7 \mathrm{~mm}, 3$ whorls preserved. No. $12335 \mathrm{H}=9.1 \mathrm{~mm}, 3$ whorls preserved.

Descriptive remarks. - The preserved first whorl of the specimen No. 12334 a is rhomboid in profile with a sharp carina slightly below the middle height. Shoulder slope and lateral side are slightly concave. Subsutural lira and other lira on lateral surface appear on the second whorl, then spirals are successively added on both shoulder slope and lateral surface. At the same time shoulder angulation is adapically shifted and finally becomes blunt. On the penultimate whorl subsutural lira and seven lateral ones are distinct and of equal size and the latter lirae are separated from one another by narrower interspaces. On 
the body whorl shoulder angulation is very weak and the shoulder slope is moderately concave to form anal sulcus on which two weak spiral threads are discernible. Anal sinus indicated by growthline is shallow v-shape with its apex at the middle of shoulder sulcus and abapical extention of its lower arm is slightly opisthocline.

Specimen No. 12335 is quite identical to the preceeding one except that the former has narrower shoulder sulcus and one more spiral lira and a few fine secondary lines on the lower part of later whorls and that the subsutural lira is modified by addition of one more spiral line above. Furthermore fine and close axial threads are discernible on the interspaces of lirae on the specimen No. 12335.

subfamily Clavatulinae H. and A. ADAMS, 1858 genus Perrona Schumacher, 1817

type-species: Perrona tritonium SCHUMACHER, 1917=Murex perrona

GMELIN, 1790=Pleurotoma perronii REEVE, 1843

\section{Perrona birmanica VREDENBURG}

Text-fig. 1, Nos. 1-4

1921, Clavatula (Perrona) birmanica VRedenburg, Rec. Geol. Surv. India, Vol. 53, Pt. 2, p. 85, pl. 12, fs. 1 and 2.

Material.-GSI Type No. 12431 from the Miocene of Thanga, and No. 12432 from the Miocene of Myauktin, Burma. Apices are not preserved on both specimens. Six and six and a half whorls are preserved respectively on No. 12431 and 12432. $\mathrm{H}=46.2 \mathrm{~mm}, \mathrm{D}=16.1 \mathrm{~mm}$ (No. 12432).

Remarks and comparison.-The present species is featured by elongatly fusiform outline, slightly bent canal, distinct basal facciole, almost smooth surface except for growth lines and basal spirals and moderately deep anal sinus, which has narrowly rounded apex at the lower part of the shallow furrow. It is also characteristic by the profile of whorls, which have shallow infrasutural furrow and overlap just below the fullow mentioned above. It, therefore, well agrees with the type species of Perrona ScHMACHER, although the former is distinctive by its less sharper subsutural collar and basal angulation than the type species of the genus.

Pleurotoma erbi HAANstra and SPIKER (1933, p. 1318, pl. 1, fs. 9 and 10) from the Upper Miocene of Benkoelen, Sumatra, must be included in Perrona as Powell (1964, p. 56) pointed out. Perrona erbi shows a similar sculpture (Text-fig. 1, No. 4) on the juvenile whorls with $P$. birmanica, but the former has less distinct subsutural collar, shallower anal depresion, lower spire-whorls, smaller pleural angle and weaker spiral lines on the later whorls than the latter.

VREDENBURG distinguished a form as a subspecies, birmanica singuensis, which was originally reported by NoEtLing (1901, p. 349, pl. 23, f. 2 and 2 a) as Clavatula fulminata KIENER from Singu. Singu form is, as VREDENBURG mentioned, somewhat smaller and smoother with only a few spiral lines on the later whorls than $P$. birmanica. As far as the mentioned difference is concerned, they may not necessarily be separated at subspecies level. Their early whorls 
are, however, notably different from each other. While granules on subsutural and suprasutural bands on early whorls equally prominent on $P$. birmanica, those on subsutural band are remarkably weaker than those on suprasutural one on Singu form. The two forms seem to be reasonably separated from each other at subspecies or higher level. Singu form is closer to $P$. erbi.

Subfamily Turrinae SwaINSON, 1840

genus Gemmula WEINKAUFF, 1875

type-species: Pleurotoma gemmata ReEve, (s.d. by Cossmann, 1896)

synonym: Eugemmula IREDALE, 1931

subgenus Paragemmula nov.

type-species: Pleurotoma (Gemmula) thyrsus VREDENBURG

Diagnosis.-Teleoconch quite similar to that of Gemmula (s.s.) Protoconch high conical, polyspiral consisting of about five volutions with vertical, some what opisthocyrtly curved axial lirae. Volutions roundly convex except for the last one with sharp median carina, on which a lira being superimposed. Peripheral carina continued to teleoconch-carina.

Comparison.-The present taxon is quite identical with Gemmula (s.s.) so far as the teleoconch is concerned, but the former has peculiar protoconch which has sharp median carina on the last volution. Its axial lirae are not inclined but almost vertical on all the volutions and its later volutions are devoid of subsutural lira with which Gemmula (s.s.) is generally provided.

It is not definitely clear whether or not the peripheral carina of protoconch is a stable character in the present species, because examined specimen is only a single. However, presence and absence of such sculpture as noted above is generally stable within turrid populations, although number of volutions with carina is rather fluctuating.

\section{Gemmula (Paragemmula) thyrsus VREDENBURG}

Text-fig. 1, No. 20

1921, Pleurotoma (Gemmula) thyrsus VRedenburg, Rec. Geol. Surv. India, Vol. 53, Pt. 2, p. 103, pl. 12, f. 11.

1964, Gemmula thyrsus, Poweld, Indo-Pacific Moll., Voì. 1, No. 5, p. 264, pl. 204, f. 4 .

Material.-GSI Type No. 12441 from the Miocene of Kyaungon, Burma.

Remarks.-There is no known species with such peculiar protoconch as described above among Gemmula-like species.

genus Ptychosyrinx THIELE, 1925

type-species: Pleurotoma (Subulata) bisinuata v. MARTENs, (o.d.) synonym: Bathybermudia HAAs, 1949

Ptychosyrinx birmanicus (VREDENBURG)

Text-fig. 1, No. 19

1921, Pleurotoma (Gemmula) birmanica VRedendurg, Rec. Geol. Surv. India, Vol. 53, Pt. 2, p. 102, pl. 12, f. 12.

1964, Gemmula birmanica, Powell, Indo-Pacific Moll. Vol. 1, No. 5, p. 264, pl. 204, f. 3. 
Material.-GSI Type No. 12442 from the Miocene of Myauktin, Burma. Nine whorls preserved. Apical part broken off. $\mathrm{H}=21.5 \mathrm{~mm}, \mathrm{D}=8.1 \mathrm{~mm}$.

Comparison.-General feature of the present specimen quite agrees with those of Gemmula WEINKAUFF, 1875, except for the anal sinus, which is moderately deep but remarkably shallower on the present specimen than on typical species of Gemmula. The upper and lower arms of the sinus of the former are not parallel to each other instead of quite parallel arms of Gemmula. Furthermore the present specimen is devoid of the subsutural distinct cord and its canal is rather shorter than typical Gemmula. In these respects, the present specimen is referred to Ptychosyrinx THIELE, 1925, although its protoconch has not been examined by the present author. The original author referred to a smaller protoconch than that of Gemmula kieneri (Dummet) $=$ G. carinata auct.

Among the species of Ptychosyrinx, the present species is characteristic with its relatively weak peripheral carina with paired lirae at upper and lower margins.

genus Xenuroturris IREDALE, 1929

type-species: Xenuroturris legitima IREDALE=

Pleurotoma cingulifera LAMARCK, (o. d.)

synonym: Clamturris IREDALE, 1931

subgenus Reticuloturris subgen. nov.

type-species: Pleurotoma (Hemipleurotoma) iris VREDENBURG

Diagnosis.-Moderately small shell of Turris group, which has sinus-cord somewhat above the maximum convexity of whorl. Canal not very long. Anal sinus moderately deep with blunt apex. Sinus-cord much heavier than other lirae and regularly crenulate. Sculpture of reticulation of distinct spiral lirae and growth threads.

Comparison.-The present taxon is closely similar to Xenuroturris IREDALE, 1929 in the profile of the shell, but the former is readily distinguished from the latter by different protoconch and sculpture. The former has low conical protoconch consisting of smooth early volutions and axially costate last one instead of axially costate polyygyrate protoconch of Xenurturris. The former, furthemore, is provided with a gemmate sinus cord and distinct growth threads rendering reticulate pattern together with spirals.

The present taxon is somewhat similar to Kuroshioturris SHuto, 1961, but they are readily distinguished from each other on the basis of the position of the sinus cord.

Pleurotoma (Drillia) djocdjocartae MARTIN (1884, p. 66, pl. 4, f. 69) and Clavatula djocdjocartae serana Fischer (1927, p. 98, pl. 214, f. 77) from the Indonesian Neogene were referred to Paradrillia (Shuto, 1969, p. 192 and PoWELL, 1969, p. 318), but their anal sinus have apices on the peripheral cord somewhat above the maximum convexity of whorl like in $P$. (H.) iris Vredenburg. Sculptural pattern is also similar among above three species. In spite of close similarity, the former two Indonesian species are distinguished from $P$. $(H$.) iris in having the protoconch with distinct carina on the later part and are 
referred to Coronacomitas SHUTo, 1983 (p. 1, pl. 2, f. 7).

Under such circumstance noted above, Reticuloturris is placed under Xenuroturris as a subgenus.

\title{
Xenuroturris (Reticuloturris) iris (VREDENBURG) \\ Text-fig. 1, No. 23
}

1921, Pleurotoma (Hemipleurotoma) iris VRedenburg, Rec. Geol. Surv. India, Vol. 53, Pt. 2, p. 98, pl. 12, fs. 14 and 15.

Material.-GSI Type No. 12444 and 12445 from the Miocene of Kyaungon, Thanga district, Burma. $\mathrm{H}=18.4 \mathrm{~mm}$ (No. 12444).

Description.-Shell is turreted with high spire and shorter base. Protoconch is low conical and shows prosocyrtly curved thin axials on last two-third volutions, although the original author described a tall trochoid protoconch with three volutions. Teleoconch-whorls are roundly convex. Anal sinus is moderately deep with its broad apex on the crenulated stout spiral code, which is situated somewhat above the maximum convexity of whorls. Growth-threads form fine crenulation at intersections with spiral threads below and above the sinus-cord, while they do not cross over the subsutural lira. Infrasutural sulcus is narrow and provided with a few fine spiral lines together with distinct growth-threads. Aperture is rhomboid and contracted at the lower part. Canal is moderately long and terminally truncated. Columellar callus and parietal entering callus are moderately thick.

Comparison.-Some species of Epidirona, i.e. E. tuberculata LASERON and $E$. costifera LASERON from the east Australian waters, have the crenulate sinus cord at some distance above the most convex part of whorl like as on the present species. The latter is distinguished from the former two species by definitely longer canal. The above mentioned characteristics of sinus cord and canal of the present species recall Paradrillia (Coronacomitas) serana (FISCHER) (1927, p. 98, pl. 214, f. 77) from Seram Island, Indonesia, which is reasonably separated from $P$. (C.) djocjocartae (MARTIN) at species level as I pointed out $(1969, \mathrm{p}$. 193). The present species is distinguished from $P$. (C.) serana in non-carinate protoconch, weaker subsutural cord and still higher position of crenulate sinus cord.

Pleurotoma sumatrana HAANSTRA and SPIKeR (1932, p. 1324, pl., f. 7 and 8) from the Upper Miocene of Southwest Sumatra is referred to Reticuloturris and resembles the present species, but is yet distinguished from the latter in having broader shell with stronger sinus cord.

\author{
genus Epalxis Cossmann, 1889 \\ type-species: Pleurotoma crenulata LAMARCK, (o.d.) \\ Epalxis singuensis (VREDENBURG) \\ Text-fig. 1, No. 22
}

1921, Pleurotoma (Hemipleurotoma) singuensis VREDENBURG, Rec. Geol. Surv. India, Vol. 53, Pt. 2, p. 98, pl. 12, f. 16. 
Material.-GSI Type No. 12446 from the Lower Miocene of Singu, Burma. Imperfect and deformed.

Remarks and comparison.-Because of imperfect preservation of the present specimen concrete reference at generic level can not be done. However, the specimen is characterized by crenulate, prominent peripheral carinal costa, on which rather broad apex of moderately deep U-shaped anal sinus is situated. Whorls have subsutural lira and a few spiral threads besides the peripheral one, which is much larger than others. Axial sculpture is not developed. On the basis of the feature mentioned above it is reasonably included in Gemmula group of Turrinae. It is readily distinguished from Gemmula by its shallower sinus without parallel arms. It is similar to Hemipleurotoma CossmanN, 1889, Ptychosyrinx THIELE, 1925 and Epalxis CossmaN, 1889 in regard to the anaI sinus with broad apex. It is, however, different from the former two genera in less contracted base and broader and less erect peripheral band on which crenulations are rather thin, vertically elongated and opisthocyrtly curved. On the basis of the last mentioned characteristics, the present species is probably included in Epalxis, although preservation is not suitable. Further comparison is very difficult because of poor preservation.

Subfamily Borsoniinae BELLARDI, 1875 genus Awateria SUTER, 1917

type-species: Awateria streptophora SuTER, (o.d.)

Awateria ? dormitor (VREDENBURG)

Text-fig. 2, No. 26

1921, Drillia dormitor VReDenburg, Rec. Geol. Surv. India, Vol. 53, Pt. 2, p. 110, pl. 14, f. 12 .

Material.-GSI Type No. 12468 from the Miocene of Dalabe, Burma. The specimen is remarkably worn and partly broken at labrum and protoconch. $\mathrm{L}=$ $8.3+\mathrm{mm}, \mathrm{W}=5.1+\mathrm{mm}$. Protoconch $1+$ volutions. teleoconch 5 whorls.

Descriptive remarks.- Shell is very small, solid and ovately biconical. Protoconch is seemingly smooth, but detail is unknown. Whorls are provided with massive subsutural rib, narrow but deep infrasutural sulcus and strong vertical axial ribs on convex lateral side. Axials are hardly developed on the sulcus, but they form distinct nodules on subsutural rib. Body whorl is weakly contracted at base. Thin spiral lirae are developed on the lower part of basal slope and on snout. Columellar lip is vertical and covered by distinct callus and the parietal lip has strong callus pad. Anal sinus is unknown because of fracture of labrum and abrasion of growth lines.

Comparison.-The specent specimen is similar to Awateria SUTER, 1917, with its characteristic shell-profile and sculpture. Concrete reference is, however, suspended because of lack of necessary information of protoconch and anal sinus. Comparing with the type-species, the present species has definitely weaker spirals. 


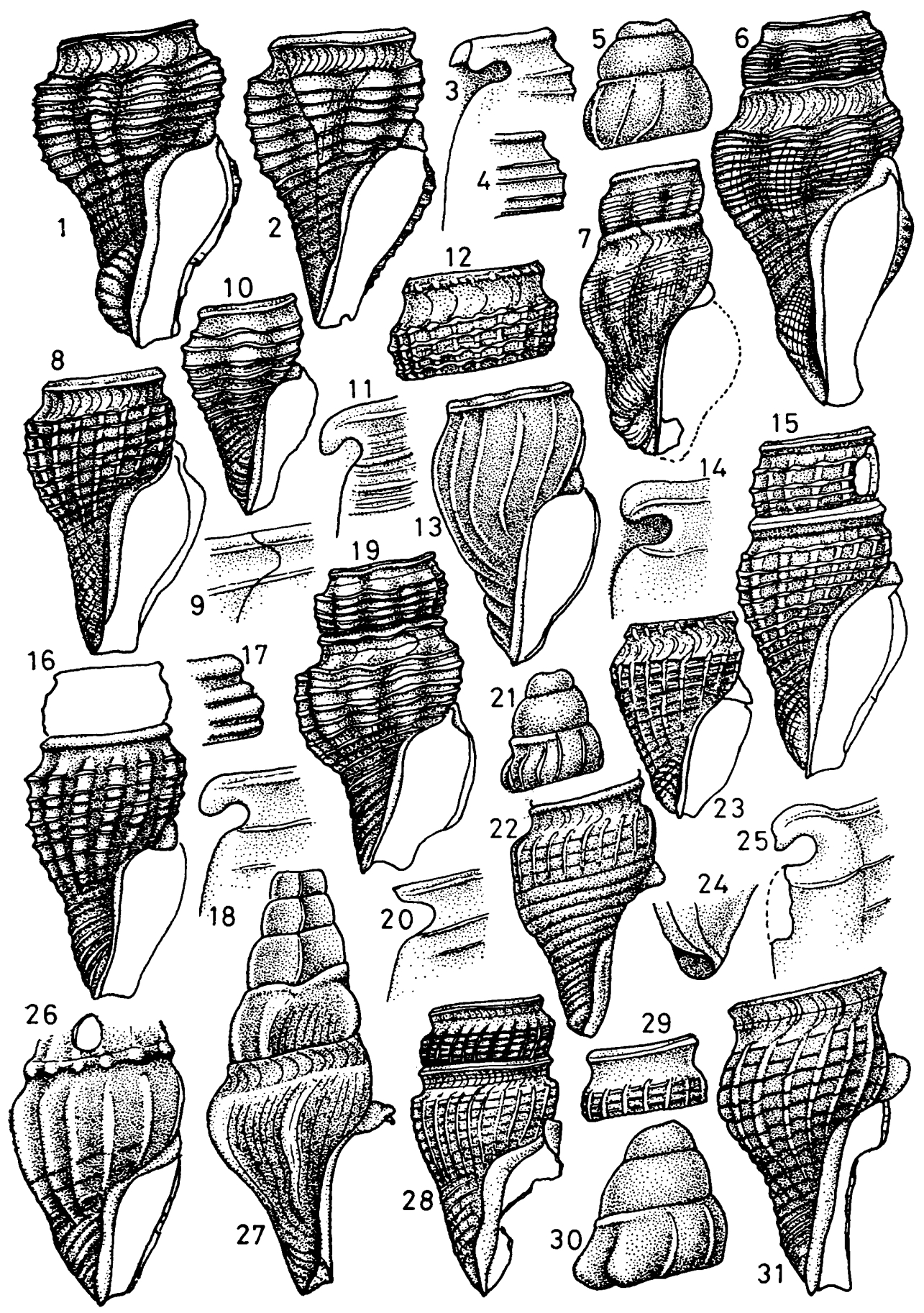


Subfamily Clavinae Powell, 1942

genus Pleuropyramis VREDENBurg, 1921

type-species: Mangilia (Clathurella) quinquangularis VREDENBURG, (o.d.)

Pleuropyramis quinquangularis VREDENBURG

Text-fig. 2, No. 27

1921, Mangelia (Clathurella) quinquangularis VREDENBURG, Rec. Geol. Surv. India, Vol. 53, Pt. 2, p. 124, pl. 14, f. 8.

1921, Mangelia (Clathurella) [sect. Pleuropyramis] quinquangularis, VREDENBURG, ibid. p. 126.

Materials.-GSI Type No. 12464 from the Miocene of Kyudawon, Burma. Specimen lacks early part of protoconch and labrum. $\mathrm{H}=22.7+\mathrm{mm}, \mathrm{D}=7.2+$ $\mathrm{mm}$. Protoconch $1+$ volutions, teleoconch 8.5 whorls.

Description.-Shell is fusiform with high spire and rather long base. Original author described the protoconch consisting more than three volutions with curved axials, but the last one volution was preserved when I examined. Protoconch is seemingly smooth. Whorls have five thin, sharp, vertical and slightly

Text-fig. 2 Burmese Tertiary turrids

1. Drillia saraswati VREDENBURG. GSI Type 12451 from Thanga.

2-4. Inquisitor pinfoldi (VREDENBURG). GSI Type 12450 from Mindegyi.

5-6. I. (Ptychobela) annandalei (VREDENBURG). GSI Type 12452 from Myaukmigon.

7. Drillia reticulata VRedenbUrg. GSI Type 12455 from Thanga.

8-9. Inquisitor subbatavianus (VREDENBURG). GSI Type 12456 from Tittabwe.

10-11. I. molengraaffi pulcherrimus (VREDENBURG). GSI Type 12447 from Tittabwe.

12. Paradrillia ? iravadica (VREDENBURG). GSI Type 12443 from Payagyigon.

13. Splendrillia indica (VRedenburG). GSI Type 12448 from Tittabwe.

14-15. Inquisitor myaukmigonensis (VREDENBURG). GSI Type 12460 from Myaukmigon.

16-18. Euclathurella (Miraclathurella) decemcostata (VREDENBURG). GSI Type 12466 from Thanga.

19-20. Pleurotomoides ? convexus (VREDENBURG). GSI Type 12454 from Myaukmigon.

21-22. Turricula (Nangulanica) birmanica (VREDENBURG). GSI Type 12462 from Tittabwe.

23-25. Crassispira (Crassispira) gautama (VREDENBURG). GSI Type 12459 from Thanga.

26. Awateria ? dormitor (VRedendurg). GSI Type 12468 from Dalabe.

27. Pleuropyramis quinquangularis VREDEnBURG. GSI Type 12464 from Kyudawon.

28. Crassispira (Crassispira) iravadica VRedenburg. GSI Type 12461 from Myaukmigon.

29-31. C. (Birmadrillia) constricta VRedenburg. GSI Type 12463 from Myaukmigon. 
opisthocyrthly curved axial ribs, which are from suture to suture and continuous from whorl to whorl except on the penultimate and body wohrl. Interspace between ribs is slightly concave. Consequently spire shows a pentagonal outline in apical view. On the penultimate and body whorl axial ribs are weakened near upper suture to form a slightly concave subsutural anal fasciole, on which growthlines are distinct. In keeping pace with development of anal fasciole, axial ribs are thickened and buldged at the most convex part of whorl. Spiral sculpture is absent even on the moderately long snout. Basal contraction is moderate. Suture is clasping and somewhat wavy particularly on the later whorls. Callus on the inner lip is very thick, particularly it is prominent with free edge on columellar lip. Parietal process is also heavy. Anal sinus indicated by growth line is moderately deep v-shape with its apex at the middle of anal fasciole and its lower arm distinctly swings forward. Stromboid notch is shallow but distinct.

Comparison.-The original author described "a rather obscure, steeply winding fold" at the middle of the columellar lip of the present specimen, but I could not observe any columellar fold under a loupe. The present specimen closely resembles Plagiostropha MELVILL, 1927 in the general facies except for longer snout and somewhat deeper anal sinus. While the anal sinus of Plagiostropha is very deep, narrowed by entering callus pad on the body whorl of full grown specimen, those shown by growthlines on spire whorls are not so deep as that of the final stage with their slightly prosocline upper arm and adaperturally swinging lower arm. Anal sinus of Pleuropyramis quinquangularis at the final stage must be as deep as in Plagiostropha, but those on spire whorls are remarkably deeper than in the latter taxon with symmetrically inclined upper and lower arms. Comparing with known four species of Plagiostropha, all living in the tropical Indo-West Pacific realm, the present species has critically longer base. Under such situation mentioned above, the present taxon is separated from the Borsoniinae and is placed in the Clavinae near Plagiostropha. Although it is not necessarily clear whether they are congeneric or not, they are here tentatively treated as independent genera.

genus Inquisitor HEDLEY, 1918

type-species: Pleurotoma sterrha WATson, (o.d.)

Inquisitor pinfoldi (VREDENBURG)

Text-fig. 2, Nos. 2-4

1921, Drillia (Brachytoma) pinfoldi VredenburG, Rec. Geol. Surv. India, Vol. 53, Pt. 2, p. 110, pl. 13, f. 4.

1962, Drillia (Brachytoma) pinfoldi VRedenburg var. DeY, Palaeontogr. Indica, N. S. Vol. 36, p. 100, pl. 8 , fs. 6 and 7 .

Material.-GSI Type No. 12450 from the Miocene of Mindeygyi, Burma. Apical part broken off. $\mathrm{H}=26.0+\mathrm{mm}, \mathrm{D}=9.7 \mathrm{~mm}$.

Descriptive remarks.-The present short fusiform specimen is characterized by very weak basal contraction, prominent subsutural lira, spiral-free deep shoulder sulcus, fold-like axial ribs, regularly spaced spiral lirae, raised growth 
lines illustrating v-shaped anal sinus, subtubular anal sinus of the final stage narrowed by heavy parietal entering callus pad, differentiated, moderately long and obliquely truncated canal and columellar lip with moderately thick but narrow callus.

Comparison.-The present species resembles both Inquisitor HEDLEY 1918 and Crassispira SwAINSON, 1840 in the general facies, but it is closer to Inquisitor by its unnotched, wider and somewhat longer canal.

Among the turrid specimens stored in the Geological Institute of the University of Amsterdam, I noticed four specimens from the Miocene of Sedan, Indonesia labeled "Surcula pamotanensis MARTIN". Two of the four specimens are not identical to MARTIN's species, but are quite similar to $I$. pinfoldi except for minor difference that 1 . pinfoldi is provided with somewhat stronger subsutural lira and almost devoid of secondary spirals.

Drillia (Austrodrillia ?) durgae BeETs from the Upper Miocene of East Kalimantan (1941, p. 126, pl. 7, fs. 276 and 268) is distinguished from Austrodrillia by its long and obliquely truncated canal and referred to Inquisitor. It closely resembles $I$. pinfoldi but is distinguished from the latter in that it is one-third as small as the latter.

\section{I. molengraffi pulcherrimus (VREDENBURG)}

Text-fig. 2, Nos. 10 and 11

1921, Drillia pulcherrima VRedendurg, Rec. Geol. Surv. India, Vol. 53, Pt. 2, p. 105 , pl. 13, f. 1.

Materials.-GSI Type No. 12447 from the Miocene of Tittabwe, Burma. Protoconch lacking. 9 whorls preserved. $\mathrm{H}=19.0 \mathrm{~mm}, \mathrm{D}=5.9 \mathrm{~mm}$.

Remarks and comparison.-The present species is featured by weakly contracted rather long base, buldged basal fasciole, thick columellar callus, prominent and solid parietal entering callus pad and subcircular anal sinus. It is referred to Inquisitor although its protoconch is not known. Among several species of Inquisitor, it is characteristic enough by its fold-like axial ribs of small number (six per one whorl) and simple design of spiral sculpture. It is closely similar to I. molengraaffi (MARTIN) (1917, p. 230, pl. 1, f. 14) from the lower Miocene of Progo Mountains, Central Java. Observed difference between them is rather slight; that is to say, the present species is somewhat slenderer than I. molengraaffi with higher spire and, furthermore, is provided with secondary and tertiary spiral lines on the basal slope instead of simple sculpture consisting of only primaries on the latter. The present specimen is better included in $I$. molengraaffi as a subspecies.

Drillia (Crassispira) scillae Bellardi of ERUNAL-Erentoz from the Upper Miocene of Adana, Turkey (1958, p. 89, pl. 14, fs. 1, la and 2, non BeLLARDI, 1877 , p. 94 , pl. 3, f. 18) is reasonably referred to Inquisitor on the basis of its morphology and it is similar to I. molengraaffi pulcherrimus, but the former is distinguished from the latter in having one and a half times larger shell with more contracted base, a few more axials per whorl and being devoid of spiral lira above shoulder angle. 


\section{I. subbatavianus (VREDENBURG)}

Text-fig. 2, Nos. 8 and 9

1921, Drillia (Crassispira) subbataviana VRedenburg, Rec. Geol. Surv. India, Vol. 53, Pt. 2, p. 118, pl. 13, f. 10.

Materials.-GSI Type No. 12456 from the Miocene of Tittabwe, Burma. Apical part broken off. $\mathrm{H}=$ ca $19 \mathrm{~mm}, \mathrm{D}=6.8 \mathrm{~mm}$.

Description.-Whorls are remarkably sulcate below strong and plain subsutural lira. The shoulder sulcus is not provided with spirals, but with dense raised growth lines. Sculpture consists of distinct and relatively thin axial ribs and regularly spaced low spiral lirae on the lateral surface. Basal surface is devoid of axials. Aperture is very long. Canal is long, wide and shallowly notched terminally. Columellar lip is straight and provided with distinct callus with free edge in upper four-fifths and moderately twisted in lower one-fifth. Moderately deep anal sinus occupies the shoulder slope and is narrowed at the entrance by moderately developed parietal callus. Basal fasciole is weak.

Comparison.-Comparing with Crassispira, the present specimen has much longer canal and weaker basal fasciole. It is reasonably referred to Inquisitor.

The original author compared the present species to Indonesian Drillia bataviana MARTIN, which is referred to Inquisitor, but the latter has more distantly spaced axial ribs, more defined shoulder angulation, fine spiral threads on shoulder sulcus and narrower anterior canal than the former.

\section{I. myaukmigonensis (VREDENBURG)}

Text-fig. 2, Nos. 14 and 15

1921, Drillia (Crassispira )myaukmigonensis VREDenbURG, Rec. Geol. Surv. India, Vol. Pt. 2, p. 121, pl. 14, f. 4.

Material.-GSI Type No. 12460 from the Miocene of Myaukmigon, Burma. Apical part missing. $\mathrm{H}=19+\mathrm{mm}, \mathrm{D}=6.0 \mathrm{~mm}$.

Descriptive remarks.-Shell is solid and fusiform, but its tapered base is not very long. Whorls are provided with prominently lirate massive subsutural fold and deep and narrow infrasutural sulcus. Sculpture of coarse lattice of erect but narrow axial ribs overriden by equally sized primary spiral lirae. Axials extend over the base and almost reach the prominent basal fasciole. Aperture is pyriform with wide, moderately short, obliquely and shallowly notched canal. Callus is distinct on columellar lip but once becomes thin on the parietal lip. Labrum is varicose outside. Anal sinus is deep, elliptical and is narrowed at the entrance by parietal process.

Comparison.-The present species is an intermediate form between Inquisitor and Crassispirella BARTSCH and REHDER, 1938 in the above mentioned feature. I am, however, inclined to include it in Inquisitor because of its more defined, longer and narrower canal than Crassispirella, although its sculpture is closer to the latter. 
subgenus Ptychobela THIELE, 1925

type-species: Pleurotoma tremularis LAMARCK, (o.d.)

\section{I. (Ptychobela) annandalei (VREDENBURG)}

Text-fig. 2, Nos. 5 and 6

1921, Drillia (Brachytoma) annandalei VRedenburg, Rec. Geol. Surv. India, Vol. 53, Pt. 2, p. 114, pl. 13, f. 6 .

Material.-GSI Type No. 12452 from the Miocene of Myaukmigon, Burma. Almost perfectly preserved. $\mathrm{H}=27.1 \mathrm{~mm}, \mathrm{D}=9.3 \mathrm{~mm}$. Protoconch ca 3 volutions, teleoconch 7.5 whorls.

Description.-Shell is elongately fusiform. Distinct shoulder sulcus is developed between the subsutural lira and the peripheral blunt angulation at three-fifths whorl-height. Protoconch is conical consisting of about three smooth and roundly convex volutions, of which the last part before the end ridge has a thin curved axial lira. Base is long, moderately contracted to broad snout. Basal fasciole is extremely strong and enclose narrow and shallow pseudoumbilicus. Axial folds are distinct only on the lateral surface and they abruptly disappear both above peripheral angulation and on the basal surface. Spiral lirae are regularly spaced on all the whorls and are intercalated by fine secondaries on the last whorl. Growth lines are distinct particularly on infrasutural sulcus. Aperture is elongately pyriform with long, wide and laterally bent canal. Columellar callus is moderately thick with free edge and continuous to parietal one. Anal sinus is broad and moderately deep v-shape with its apex at about middle of shoulder sulcus and is narrowed at the entrance by a thick parietal callus. Labrum is thin and sharp at the margin and is provided with distinct stromboid sinus.

Comparison.-The present species is characterized by elongate fusiform profile, distinct anal fasciole on shoulder sulcus, strong basal fasciole, pseudoumbilicus, long and bent canal and stromboid sinus on labrum. There is no exactly referable genus, but it is close to Brachytoma SwAINSON, 1840, Strombinoturris HERTLEIN and STRONG, 1951 and Inquisitor. It is distinguished from Strombinoturris in having spiral-free shoulder sulcus, coarsely spaced axial folds and terminally truncated canal.

It is separated from Brachytoma in having both axial folds and distinct spiral lirae, stronger basal fasciole, distinct subsutural lira and unnotched, somewhat bent canal.

Still it does not quite conform with Inquisitor (s.s.) because of its stronger basal fasciole, spiral-free, wider anal sulcus and closest to Ptychobela THIELE, 1925.

Pleurotoma pamotanensis MARTIN from the lower Middle Miocene of Rembang, Java (1906, p. 292, pl. 43, fs. $701,701 \mathrm{a}, 701 \mathrm{~b}$, and $701 \mathrm{c}$ ) is also referred to Ptychobela. I. (P.) annandalei is a close ally to $I$. $(P$.) pamotanensis and is just distinguished from the latter in having wider shoulder sulcus, somewhat weaker axial folds slightly closer spiral lirae and more conical protoconch. 
genus Drillia GraY, 1937

type-species: Drillia umbilicata GraY, (s.d. by GraY, 1847)

\section{Drillia saraswati VREDENBURG}

Text-fig. 2, No. 1

1921, Drillia (Brachytoma) saraswati VRedenburg, Rec. Geol. Surv. India, Vol. 53, Pt. 2, p. 114, pl. 13, f. 5 .

Material.-GSI Type No. 12451 from the Miocene of Thanga, Burma. Apical part broken off. $\mathrm{H}=35+\mathrm{mm}, \mathrm{D}=12.1 \mathrm{~mm}$.

Comparison.-The present specimen is featured by prominent basal fasciole, distinct pseudoumbilicus, pyriform aperture with wide canal, heavy parietal callus pad and moderately deep v-shaped anal sinus occupying shoulder sulcus. It well agrees with Drillia GRAY, 1838, but it has more developed canal without remarkable notch and less developed callus on inner lip. It is also somewhat similar to Ptychobela THIELe, 1925, but is still distinguished from the latter in having the massive basal fasciole with distinct pseudoumbilicus. The present species stands at an intermediate position between Drillia and Ptychobela, but it is tentatively placed in Drillia evaluating basal feature.

Its primary spirals on the early whorls are four, subsutural lira and three lateral ones below shoulder sulcus, of which the second lower one is the strongest. Axial folds are abruptly weakened on the basal slope, but just reach the basal fasciole, while they immediately disappear above sharp shoulder angulation. Shoulder sulcus is free from spirals but is provided with distinct growthlines. Basal surface has weaker spirals which are more distantly spaced than on the lateral surface.

There is a similar species from the Upper Miocene of Tji Djavian, Banjaemas, Java, which is labelled "Drillia palabuanensis MARTIN" in the Museum of Geological Institute, University of Amsterdam (Reg. No. M. 235, 2 specimens). The latter is included in Drillia and is distinguished from $D$. palabuanensis which is really referred to Inquisitor. $D$. sp. from Tji Djarian is closer to Drillia than D. sarawati is and is readily distinguished from the latter in having wider canal, wider shoulder sulcus and regular spirals consisting of only primary lirae, which are weakened between axial ribs.

\section{D. reticulata VREDENBURG}

Text-fig. 2, No. 7

1921, Drillia (Brachytoma) reticulata VREdenburg, Rec. Geol. Surv. India, Vol. 53, Pt. 2, p. 115, pl. 13, f. 9.

Materials.-GSI Type No. 12455 from the Miocene of Thanga, Burma. Apical part and labrum broken off. 3.3 whorls preserved. $\mathrm{H}=27+\mathrm{mm}, \mathrm{D}=8.2+$ $\mathrm{mm}$.

Comparison.-Extremely prominent basal fasciole and deep pseudoumbilicus suggest that the present specimen is allied to a generic group of Drillia. It is provided with bold axial plicae and is covered wholly with reticulation of dense spiral threads and lines crossed by growth lines. Anal sinus 
shown by growthline is broad and moderately deep on spiral-free shoulder slope. Thick callus of inner lip is continuous from the anterior end to the posterior end, where a gutter is formed. These characteristics are in common with Drillia (s.s.). However, the present species represents a peculiar group within Drillia featured by very high spire and long body whorl. The present species shows a tendency of weakening sculpture on body whorl. There is no comparable species.

genus Splendrillia HEDLEY, 1922

type-species: Drillia weesi BeDDome, (o.d.)

Splendrillia indica (VREDENBURG)

Text-fig. 2, No. 13

1921, Drillia indica Vredenburg, Rec. Geol. Surv. India, Vol. 53, Pt. 2, p. 107, pl. 13, f. 2.

Material.-GSI Type No. 12448 from the Miocene of Tittabwe, Burma. Apical part missing. $\mathrm{H}=15.0+\mathrm{mm}, \mathrm{D}=5.5 \mathrm{~mm}$.

Remarks.-The present specimen is similar to Inquisitor in the major characteristics in shell-design, aperture, anal sinus etc., but is not quite identical to the latter in having roof-shaped moderately weak axials extending from just below the very narrow infrasutural sulcus to the snout. In this respect, the present specimen looks like Syntomodrillia WoodRING, 1928, but is readily distinguished from the latter in having distinct subsutural cord. It is also distinguished from Cymatosyrinx DALL, 1889 in having terminally truncated and well developed canal instead of deeply notched one of the latter, although their protoconchs are not compared. The original author described protoconch, on the basis of other identical specimens, consisting of nuclear and following two smooth volutions, but the holotype lacks the protoconch. In conclusion the present species is included in Splendrillia HEDLEY, 1922.

As a Splendrillia, the present species is characteristic with reversed-sigmoidally curved, roof-shaped moderately weak axials and makes up a species group together with $S$. persica SMITH, S. lucida GARRET and NeviL, etc. living in Indian Ocean and adjacent waters.

genus Crassispira SWAINSON, 1840

type-species: Pleurotoma bottae Kiener, (s.d. by Herrmannsen, 1847) subgenus Crassispira (s.s.)

Crassispira (Crassispira) gautama (VREDENBURG)

Text-fig. 2, Nos. 23-25

1921, Drillia (Brachytoma) gautama VREdenburG, Rec. Geol. Surv. India, Vol. 53, Pt. 2, p. 116, pl. 14, f. 3.

Materials.-GSI Type No. 12459 from the Miocene of Thanga, Burma. Protoconch missing. 8.5 whorls preserved. $\mathrm{H}=26.0+\mathrm{mm}, \mathrm{D}=8.9 \mathrm{~mm}$.

Remarks.-Although protoconch is not preserved, the present specimen is reasonably referred to Crassispira SwAINSON, 1840, on the basis of the following 
feature; granulated subsutural lira, moderately excavated wide shoulder sulcus with moderately deep v-shaped growth threads, hardly contracted, rather short base with distinct basal fasciole, elongately ovate aperture with very short, terminally notched canal and subtubular anal sinus narrowed by parietal process.

Crassispira erebus PILSBRY and Lowe from off Nicaragua (1932, p. 49, pl. 2, f. 10) is somewhat similar to the present species, but has weaker spirals and narrower infrasutural sulcus than the latter.

\section{C. (C.) iravadica VREDENBURG}

Text-fig. 2, No. 28

1921, Drillia (Crassispira) iravadica VRedenburg, Rec. Geol. Surv. India, Vol. 53, Pt. 2, p. 121 , pl. 14, f. 5 .

Material.-GSI Type No. 12461 from the Miocene of Myaukmigon, Burma. Apical part and labrum broken off. 5.5 whorls preserved. $\mathrm{H}=18.5+\mathrm{mm}, \mathrm{D}=6.9+$ $\mathrm{mm}$.

Remarks.-Hardly contracted base with strong fasciole, distinct subsutural fold with sharp ridge at its lower margin, deeply excavated infrasutural anal sulcus, sculpture of thin but erect axial ribs and spiral lirae which do not override the axials and moderately deep anal sinus are the characteristic feature of the present specimen. It is cloesly similar both to Crassispira (s.s.) and Crassispirella BARTSCH and REHDER, 1938. Its sharply keeled subsutural fold and adult sculpture suggests its relation to Crassispirella, but its prominent columellar and parietal callus claims its close relation to Crassispira (s.s.). Evaluating the last mentioned feature, the present species is here referred to Crassispira (s.s.). As a Crassispira species, the present species is featured by following characteristics; i.e. very sharp shoulder angle, slightly opisthocline axial ribs, dense and regular spiral lirae separated only by narrower grooves, thick callus on columellar lip with free edge, distinct parietal callus, subtubular anal sinus narrowed at entrance by small but strong parietal process and anal sulcus with both faint spiral lines and raised growth lines.

Drillia anthamilla Melvill (1928, p. 163, pl. 4, f. 1) is somewhat similar to the present species, but has blunter shoulder angle and more raised spirals which cross over axials.

subgenus Birmadrillia nov.

type-species: Drillia (Crassispira) constricta VREDENBURG

Diagnosis.-A small clavid shell with basic morphology of Crassispira but with collar-like subsutural part, somewhat longer canal and polygyrate protoconch.

Description.-Shell is small and fusiform. Protoconch is conical consisting of about three volutions which are smooth except for the last quarter with distantly spaced thin axial lirae. Early teleoconch whorls are provided with prominent subsutural band superimposed by a lira, deep infrasutural sulcus without sculpture but growth lines, and convex lateral side with lattice sculpture consisting of thin but erect axial ribs and raised spiral lirae. Later whorls are 
deeply excavated below subsutural lira. The sulcus has its deepest part close to its lower boundary and is tapered toward the highest part of the subsutural lira like a collar. Anal growth lines on the sulcus are fine. Lateral side below sulcus is roundly convex. Sculpture consists of opisthocline thin axial ribs and regularly spaced spiral grooves on the lateral side. Axials are abruptly weakened and overriden by thin but raised spiral lirae on the contracted base. Columellar lip is slightly oblique, long and provided with thick callus. Anal sinus is deep with broad apex and narrowed at the entrance by prominent parietal process. Canal is rather long and shallowly notched at terminal.

Comparison.-The present taxon shows closely similar feature to Crassispira, but is characteristic by its protoconch consisting of more numerous volutions, collar-like subsutural lira and infrasutural sulcus, broad spiral costae separated by narrow grooves, and longer canal. Evaluating the quite conformable morphology in the early whorls of the present taxon with Crassispira, I am inclined to place the former as a subgenus of the latter.

\section{C. (Birmadrillia) constricta VREBENBURG}

Text-fig. 2, Nos. 29-31

1921, Drillia (Crassispira) constricta VRedenburg, Rec. Geol. Surv. India, Vol. 53, Pt. 2, p. 121, pl. 14, f. 7 .

Material.-GSI Type No. 12463 from the Miocene of Myaukmigon, Burma. The specimen lacks the labrum, which the original author illustrated in the plate. $\mathrm{H}=15.0 \mathrm{~mm}, \mathrm{D}=4.5+\mathrm{mm}$. Protoconch 3 volutions, teleoconch 6 whorls.

Remarks.-Apical part of the specimen is somewhat worn and exact original morphology can not necessarily observed. However, beginning of its teleoconch is clearly indicated by abrupt appearance of subsutural lira and succeedingly of the first axial rib, which is weakened below the subsutural lira. Morphology of the third and fourth whorls are quite identical with those of Crassispira as noted above. Lateral side of later whorls are regularly rounded and the basal contraction is moderate. Collar-like subsutural part has obscure growthlines and a central spiral thread.

Drillia palembangensis HAANSTRA and SPIKER (1932, p. 1327, pl., fs. 5 and 6) from the Upper Miocene of Sumatra has typical collar-like subsutural band and is included in Birmadrillia. It is similar to $C$. (B.) constricta, but is distinguished from the latter in more numerous axial ribs and weaker development of subsutural color.

\section{C. ? subpromensis VREDENBURG}

Text-fig. 3, Nos. 1 and 2

1921, Drillia (Crassispira) subpromensis VREDENBURG, Rec. Geol. Surv. India, Vol. 53, Pt. 2, p. 118, pl. 14, f. 15.

Material.-GSI Type No. 12471 from the Miocene of Kyudawon, Burma. Apical part of protoconch and anterior part of aperture are not preserved. $\mathrm{H}=9.6+\mathrm{mm}, \mathrm{D}=5+\mathrm{mm}$. Protoconch 2.3 volutions, teleoconch 7.3 whorls.

Remarks.-The present small specimen is featured by conical polyspiral pro- 
toconch with a few brephic axials on later 0.4 volution, wide and moderately deep anal sulcus below simply lirate subsutural fold. Parietal process and columellar callus are strong. It belongs to Crassispira group and shows affinity to Birmadrillia, but its anal sulcus is not tapered but normally concave and its sculpture is reticulation with granules at intersections of low axials and stronger spirals. Accordingly the present species does not conform with Birmadrillia. It is tentatively included in Crassispira.

Subfamily Conorbiinae POWELL, 1942

genus Genota H. and A. ADAMs, 1853

type-species: Buccinum mitriformis Wood, (s.d. by Fischer, 1883)

synonym: Genotia FISCHER, 1883

Genota? singuensis (VREDENBURG)

Text-fig. 1, No. 25

1921, Genotia singuensis VRedenburg, Rec. Geol. Surv. India, Vol. 53, Pt. 2, p. 132 , pl. 15 , f. 1 .

Material.-GSI Type No. 123331 from the Singu Stage of Singu, Burma. 3 whorls preserved.

Descriptive remarks.-Details of morphology is not known because of unsuitable preservation. The specimen is, however, considered to have long and slender profile judging from the high profile of slowly growing whorls and hardly contracted base. Whorls have broad subsutural band with three spiral lirae, distinct infrasutural sulcus free from spirals and slightly convex lateral side sculptured with thin axial ribs overriden by alternating stronger and weaker spirals. Axials are parallel with growth lines and counted about 30 on the last whorl. Spirals on basal slope are stronger than those on lateral surface. Anal sinus is shallow and broad with its apex at upper two-fifths of the infrasutural sulcus. Its lower arm does not distinctly swing forward, but is gently curved abapically.

Comparison.-Generic status of the present species is not clear. It may included in Genota H. and A. ADAMS, 1853, on the basis of above noted characteristics. It lacks anterior part of the body whorl and superficially similar to Leptosurcula CASEY, 1904, but is distinguished from the latter in having narrower anal sinus, more regular axial ribs and more defined shoulder sulcus. Comparison at species level is difficult because of unsuitable preservation.

Subfamily Mangeliinae Fischer, 1887

genus Pleurotomoides BRoNN, 1831

type-species: Defranica pagoda Millet, (s.d. by DALL)

Pleurotomoides ? convexus (VREDENBURG)

Text-fig. 2, Nos. 19 and 20

1921, Drillia (Brachytoma) convex VRedenburg, Rec. Geol. Surv. India, Vol. 53, Pt. 2, p. 116, pl. 13, f. 8.

Material.-GSI Type No. 12454 from Miocene of Kyaukmigon, Burma. 


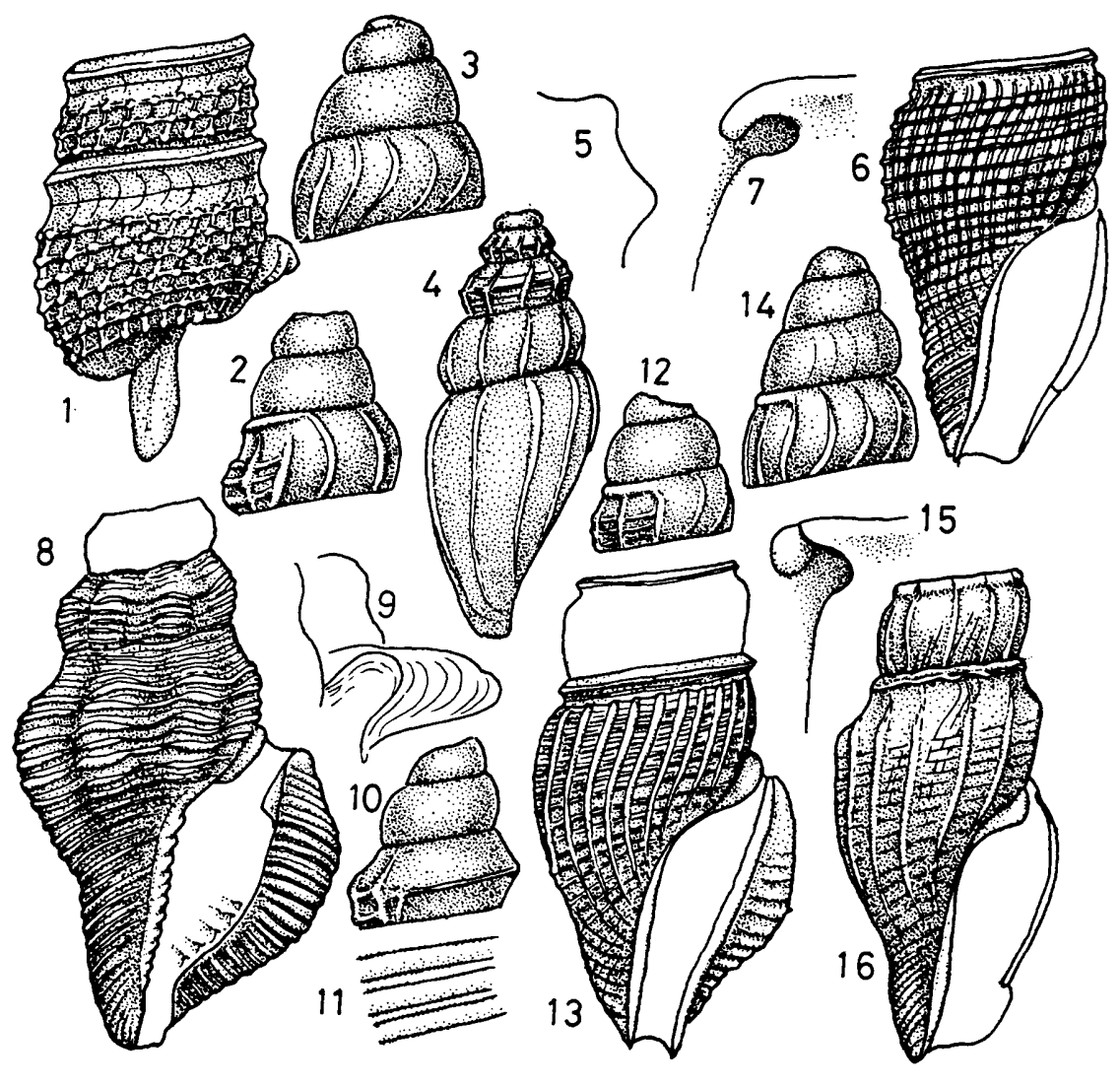

Text-fig. 3 Burmese Tertiary turrids

1-2. Crassispira ? subpromensis VREDENBURG. GSI Type 12471 from Kyudawon.

3,6 and 7. Euclathurella (Miraclathurella) elegantissima (VREDENBURG). GSI Type 12467 from Dalabe.

4-5. Cytharella ? birmanica (VREDENBURG). GSI Type 12470 from Dalabe. 5, outline of whorl in axial view.

8-11. Lioglyphostoma martini (VREDENBURG). GSI Type 12469 from Thanga. 9 , anal sinus in oblique view; 11 , spiral sculpture in detail.

12-13. Euclathurella (Miraclathurella) tittabweensis (VREDENBURG). GSI Type 12457 from Tittabwe.

14-16. E. (M.) dalabeensis (VRedenburg). GSI Type 12465 from Dalabe.

Apical part missing. $\mathrm{H}=15.9+\mathrm{mm}, \mathrm{D}=5.7 \mathrm{~mm}$.

Comparison.-Characteristic feature of teleoconch of the present specimen well conforms with that of Pleurotomoides BronN, 1831. That is to say, tabulate whorls with sharp shoulder angulation, strong basal contraction, moderately long and wide canal with distinct notch, remarkably twisted columellar lip, well defined stromboid notch on labrum, moderately deep v-shape anal growth lines on shoulder sulcus, deep v-shaped anal sinus on labrum and rather regularly cancellate sculpture are in common on both the present specimen and the representative species of Pleurotomoides. However, the former has wider canal 
than the latter. Besides, it lacks the apical part and the protoconch is unknown. In consequence, concrete reference to Pleurotomoides is suspended here.

The present species is somewhat similar to Platycythara WoODRING, 1928, but the latter is devoid of subsutural lira and definite basal contraction and is provided with axials stretching to shoulder slope in spite of similarity in the basic feature.

genus Euclathurella WoodRING, 1928

type-species: Clathurella verndryesiana DALL, (o. d.)

subgenus Miraclathurella Woodring, 1928

type-species: Miraclathurella vittata WoodRING, (o.d.)

Euclathurella (Miraclathurella) tittabweensis (VREDENBURG)

Text-fig. 3, Nos. 12 and 13

1921, Drillia (Crassispira) tittabweensis VREDenbUrG, Rec. Geol. Surv. India, Vol. 53, Pt. 2, p. 118, pl. 14, f. 1.

1962, Drillia (Crassispira) logani DeY, Mem. Geol. Surv. India, Vol. 36, p. 100, pl. 8 , fs. 10 and 12 ; pl. 9 , f. 2.

Material.-GSI Type No. 12457 from the Miocene of Tittabwe, Burma. Almost perfectly preserved except for the very tip of the protoconch. $H=17.1 \mathrm{~mm}$, $\mathrm{D}=5.6 \mathrm{~mm}$. Protoconch $2+$ cal volutions, telecoconch 6.5 whorls.

Descriptive remarks and comparison.-Protoconch of the present specimen is conical consisting of roundly convex, smooth volutions and is provided with a few opisthocyrtly curved thin axial threads on the last part. Teleoconch starts with abrupt appearance of distinct subsutural lira and other three lirae on lateral surface. Strong plain subsutural lira, very narrow but deep infrasutural sulcus, regular cancellation of weakly curved thin axial ribs and raised spiral lirae and threads, very weak contraction on base, long and narrow aperture with deep subtubular anal sinus narrowed at its entrance by thick parietal callus pad, prominently variced labrum and shallowly notched anterior canal of the present species together with characteristic protoconch suggest its taxonomic position in Miraclathurella WoODRING, 1928.

Drillia (Crassispira) logani DEY (1962, p. 100, pl. 8, fs. 10 and 12; pl. 9, f. 2) from the Middle Miocene of Quilon, South India is a close ally to the present species. They conform almost perfectly with each other except that $D$. (C.) logani has weaker secondary spirals than the present species. That renders the former a crude appearance of sculptural pattern. I am inclined to consider them conspecific.

\section{E. (M.) decemcostata (VREDENBURG) \\ Text-fig. 2, Nos. 16-18}

1921, Drillia (Crassispira) cotteri VREDENBURG var. decemcostata VREDENBURG, Rec. Geol. Surv. India, Vol. 53, Pt. 2, p. 122, pl. 14, f. 10.

Material.-GSI Type No. 12466 from the Miocene of Thanga, Burma. Early part of protoconch missing. $\mathrm{H}=10.1+\mathrm{mm}, \mathrm{D}=3.4 \mathrm{~mm}$. Protoconch $2.2+$ volutions, teleoconch 5.5 whorls. 
Description.-Shell is very small and fusiform. Protoconch is conical consisting of about 2.5 smooth volutions. Abrupt appearance of the subsutural lira indicates beginning of the teleoconch. The second to fourth whorls are provided with strong subsutural lira, narrow and deep infrasutural sulcus and three strong spiral lirae separated one another by narrower grooves on the convex lateral surface. Convexity of whorl becomes distinct on later whorls. Axials are abruptly weakened above the uppermost lateral lira and do not cross over the sulcus, while they reach the basal contraction. Axial ribs are erect, prominent and much wider than interspaces. Spirals become relatively small through growth stages but still erect particularly on the axials. Snout has regular, oblique spiral threads. Aperture is elongate pyriform with wide, rather short, shallowly notched canal. Columellar lip is provided with moderate callus. Parietal callus is very thin but the process is prominent. Anal sinus is deep, subelliptical, somewhat apart from the upper suture, and narrowed at entrance by parietal process. Labrum has strong varix outside.

Comparison.-The present taxon is readily referred to Miraclathurella on the basis of its general feature except that the former is devoid of brephic axials on the protoconch. Appearance of a few brephic axials on the latest part of protoconch may reflect delay of metamorphosis and does not necessarily indicate a difference in lineage. The present species is here included in Miraclathurella.

The present taxon is readily distinguished from Drillia (Crassispira) cotteri VREDENBURG, which is included in Inquisitor as noted before.

\section{E. (M.) elegantissima (VREDENBURG)}

Text-fig. 3, Nos. 3,6 and 7

1921, Mangelia elegantissima Vredenburg, Rec. Geol. Surv. India, Vol. 53, Pt. 2, p. 124, pl. 14, f. 11.

Material.-GSI Type No. 12467 from the Miocene of Dalabe, Burma. Perfectly preserved. $\mathrm{H}=8.4 \mathrm{~mm}, \mathrm{D}=2.9 \mathrm{~mm}$. Protoconch 3.2 volutions, teleoconch 3.6 whorls.

Descriptive remarks and comparison.-Shell is minute and ovately fusiform. Protoconch is bluntly conical consisting of dome-shaped first and a half volutions and roundly convex succeeding ones, of which the last three-fifth volutions are provided with prosocyrtlyy curved thin axials. Beginning of teleoconch is clearly marked by abrupt appearance of subsutural lira and the following vertical axial ribs. Later whorls are regularly reticulated by thin, close and slightly antisigmoidally curved axial lirae and sharply raised, dense and somewhat weaker spiral lirae. Subsutural lira is smooth and much larger than other spirals. Axials disappear on the very narrow infrasutural sulcus. Body whorl is roundly convex at sides and weakly contracted at base where axials gradually disappear. Aperture is pyriform with wide, open, moderately long canal, which is subtruncated terminally. Columellar callus is distinct with free edge on lower half. No parietal callus sheet but process is massive to narrow the entrance of deep and subelliptical anal sinus. Labrum is varicose outside. 
The present species quite conforms with Miraclathurella in the general feature of both protoconch and teleoconch.

\section{E. (M.) dalabeensis (VREDENBURG) \\ Text-fig. 3, Nos. 14-16}

1921, Drillia (Crassispira) dalabeensis VREDENBurg, Rec. Geol. Surv. India, Vol. 53, Pt. 2, p. 122, pl. 14, f. 9.

Material.-GSI Type No. 12465 from the Miocene of Dalabe, Burma. Almost perfectly preserved. $\mathrm{H}=18.0 \mathrm{~mm}, \mathrm{D}=6.1 \mathrm{~mm}$. Protoconch 3.5 volutions, teleoconch 5.5 whorls.

Description.-Shell is small and mitriform. Protoconch is conical and polygyrate with 3.5 volutions, of which last two are provided with opisthocyrtly curved thin axial lirae. Teleoconch has a distinct subsutural lira throughout growth stages. A very narrow and moderately deep infrasutural sulcus separates the subsutural lira and convex lateral side on the spire-whorls and it develops to become a rather wide and shallow shoulder sulcus on the body whorl. Axial ribs are vertical, thin, from suture to suture on the spire but are notably weakened on the subsutural lira. They are gradually weakened on base to disappear near the boundary between basal slope and snout. Interspaces between axials are provided with fine spiral threads. Spirals are much stronger on snout and almost absent or very obscure on the shoulder sulcus, on which growth lines are rather distinct. Aperture is elongately pyriform with wide, short and terminally notched canal. Columellar lip is vertical, straight and has distinct callus. Parietal callus pad is thick but does not join with the upper rim of the shallowly v-shaped anal sinus, which is just below the suture and moderately shallow with its lower arm abruptly bent vertically. Labrum is thin and simple.

Comparison.-The present species is very similar to Mitraguraleus LASERON, 1954, with Mitra-like profile and sculpture, weakly differentiated, wide and terminally notched canal and polygyrate protoconch with brephic axials on later volutions, but it has moderately shallow v-shaped anal sinus instead of reversed L-shaped one of Mitraguraleus and, besides, it is provided with a distinct subsutural lira. It is referred to Miraclathurella.

genus Lioglyphostoma WoODRING, 1928

type-species: Lioglyphostoma adematum WoodRING, (o.d.)

\section{Lioglyphostoma martini (VREDENBURG)}

Text-fig. 3, Nos. 8-11

1921, Mangilia (Clathurella) martini VREDENBurg, Rec. Geol. Surv. India, Vol. 53, Pt. 2, p. 124, pl. 14, f. 13.

Material.-GSI Type No. 12469 from the Miocene of Thanga, Burma. Almost perfectly preserved. $\mathrm{H}=18.1 \mathrm{~mm}, \mathrm{D}=8.6 \mathrm{~mm}$. Protoconch $2.8+$ volutions, teleoconch 7 whorls.

Description.-Shell is moderately small. Protoconch is conical and polyspiral consisting of more than three smooth volutions, of which earlier ones are 
roundly convex and last three-quarters are sharply carinate at middle height. Shoulder sulcus is not clearly differentiated on early whorls and it is developed on the penultimate and body whorls. Sculpture of fold-like axials overriden by spiral lirae. Axials are prominent on lateral surface but are abruptly weakened above on the shoulder slope and hardly reach the upper suture and also abruptly faded away below on the basal slope. Spirals are close consisting of alternating primary lirae and secondary lines on lateral and basal surfaces. They are particularly strong on axials ribs. Shoulder sulcus has only thin spiral lines. Aperture is eleongately pyriform with moderately short but well defined and anteriorly truncated canal. Columellar lip has numerous, dense denticles on weak callus. Parietal callus pad is prominent to narrow the entrance of deep $\mathrm{u}$-shaped anal sinus. Labrum is provided with prominent varix outside and thick callous process inside below the sinus and several laterally elongate denticles on the lower part.

Comparison.-The present species is similar both to Glyphostoma GABB, 1872, and Lioglyphostoma WooDRING, 1928, in the general facies. However, it slightly differs from Glyphostoma in having keeled volutions of smaller number on protoconch, shorter canal and less developed anal fasciole than the latter. It is, furthermore, provided with massive axial folds of small number instead of numerous rather thin axials of Glyphostoma. It is quite identical with Lioglyphostoma except for much more numerous denticles both columellar and outer lips. In short, it is an intermediate form between Glyphostoma and Lioglyphostoma, but is closer to the latter.

Clathurella costicrenata CossmanN (1900, p. 47, pl. 3, fs. 16 and 17) from the Upper Miocene of Karikal, south India is another representative of the intermediate form between Glyphostoma and Lioglyphostoma and it is also closer to the latter genus by the same reason as in the case of L. martini. L. costicrenatum is distinguished from $L$. martini in having lower spire with smaller apical angle, axial folds of larger number and less contracted base. They are the closest forms to the true Glyphostoma among allied taxa of the Indo-Pacific realm, and those intermediate forms disappeared by the Pliocene from that realm.

genus Cytharella Monterosato, 1875

type-species: Murex costatus Donovan, (s.d. Woodring)

Cytharella ? birmanica (VREDENBURG)

Text-fig. 3 , Nos. 4 and 5

1921, Daphnella (Raphitoma) birmanica VREDEnburg, Rec. Geol. Surv. India, Vol. 53, Pt. 2, p. 126, pl. 14, f. 14.

Material.-GSI Type No. 12470 from the Miocene of Dalabe, Burma. Fairly well preserved except for apical part of protoconch, but aperture is not observable because that part is not detouched from sandstone. $\mathrm{H}=6.9+\mathrm{mm}, \mathrm{D}=2.7$ $\mathrm{mm}$. Protoconch $0.8+$ volutions, teleoconch 3.5 whorls.

Remarks.- Shell is minute and ovately fusiform. The last volution of protoconch is depressed, round-sided and smooth. The first whorl of teleoconch is 
Table 1. List of turrid species of the Burmese Tertiary

\begin{tabular}{|c|c|c|}
\hline revised name & original name & \\
\hline \multicolumn{3}{|l|}{ Turriculinae } \\
\hline $\begin{array}{c}\text { Turricula sethurame } \\
\text { (VREDENBURG) }\end{array}$ & $\begin{array}{l}\text { Surcula sethuramae } \\
\text { VREDENBURG* }\end{array}$ & 1921 c, p. 88 \\
\hline $\begin{array}{c}T . \text { navarchus thangaensis } \\
\text { (VREDENBURG) }\end{array}$ & S. thangaensis VREDENBURG* & 1921 c, p. 88 \\
\hline$T \cdot$ promensis (VREDENBURG) & S. promensis VREDENBURG & 1921b, p. 304 \\
\hline $\begin{array}{c}\text { T. promensis silistrensis } \\
\text { (VREDENBURG) }\end{array}$ & $\begin{array}{l}\text { S. promensis silistrensis } \\
\text { VREDENBURG }\end{array}$ & $1921 b$, p. 308 \\
\hline T. ? protonodifera (NOETLING) & $\begin{array}{l}\text { Clavatula protonodifera } \\
\text { NoETLING }\end{array}$ & 1901, p. 350 \\
\hline $\begin{array}{c}\text { T. (Nangulanica) birmanica } \\
\text { (VREDENBURG) }\end{array}$ & $\begin{array}{l}\text { Drillia (Crassispira) } \\
\text { birmanica VREDENBURG* }\end{array}$ & 1921 c, p. 121 \\
\hline $\begin{array}{c}\text { Antimelatoma ? buddhaica } \\
\text { (VREDENBURG) }\end{array}$ & D. $\underset{\text { VREDENBURG* }}{(\text { Brachytoma }}$ buddhaica & $1921 \mathrm{c}$, p. 115 \\
\hline $\begin{array}{c}\text { Nihonia ? birmanica } \\
\text { (VREDENBURG) }\end{array}$ & Surcula birmanica VREDENBURG* & 1921c, p. 90 \\
\hline Pleurofusia fusus VREDENBURG & $\begin{array}{l}\text { S. (Pleurofusia) fusus } \\
\text { VREDENBURG* }\end{array}$ & 1921 c, p. 90 \\
\hline P. phasma VREDENBURG & S. (P.) phasma VREdenBURG* & 1921c, p. 93 \\
\hline P. feddeni feddeni (NoEtLING) & $\begin{array}{c}\text { Fasciolaria feddeni NoETLING } \\
=\text { Surcula (Pleurofusia) } \\
\text { scala var., VREDENBURG }\end{array}$ & $\begin{array}{l}\text { 1895, p. } 35 \\
\text { 1921c, pl. } 12, \\
\text { f. } 10\end{array}$ \\
\hline $\begin{array}{l}P . \text { feddeni iravadica } \\
\text { VREDENBURG }\end{array}$ & $\begin{array}{c}\text { Surcula (Pleurofusia) iravadica } \\
\text { VREDENBURG* }\end{array}$ & 1921c, p. 90 \\
\hline$P . \underset{\text { VREDENBURG }}{(\text { Neopleurofusia) scala }}$ & $S .(P$.$) scala VREDENBURG$ & 1921a, p. 282 \\
\hline $\begin{array}{c}P . \text { (Pseudofusia ?) yabei } \\
\text { VREDENBURG }\end{array}$ & $\begin{array}{c}\text { Drillia }(\text { Brachytoma) yabei } \\
\text { VREDENBURG* }\end{array}$ & 1921c, p. 113 \\
\hline $\begin{array}{c}\text { Paradrillia ? iravadica } \\
\text { (VREDENBURG) }\end{array}$ & $\begin{array}{l}\text { Pleurotoma (Hemipleurotoma) } \\
\text { humilis iravadica } \\
\text { VREDENBURG* }\end{array}$ & 1921 c, p. 98 \\
\hline$P$. ermelingi (MARTIN) & $\begin{array}{c}\text { Drillia ermelingi MATTIN, } \\
\text { VREDENBURG }\end{array}$ & 1921 c, p. 103 \\
\hline $\begin{array}{r}\text { Cosmasyrinx scabumianus } \\
\text { karenaica (NoETLING) }\end{array}$ & Surcula karenaica NOETLING & 1901 , p. 344 \\
\hline $\begin{array}{c}\text { Eosurcula irravadica } \\
\text { (NoETLING) }\end{array}$ & $\begin{array}{l}\text { Pleurotoma (Cryptoconus) } \\
\text { irravadicus NoETLING* }\end{array}$ & 1895 , p. 41 \\
\hline E. garrowi (VREDENBURG) & Genotia garrowi VREDENBURG* & 1921d, p. 132 \\
\hline E. birmanica (VREDENBURG) & G. birmanica VREDENBURG* & 1921d, p. 132 \\
\hline \multicolumn{3}{|l|}{ Clavatulinae } \\
\hline $\begin{array}{c}\text { Perrona birmanica } \\
\text { VREDENBURG }\end{array}$ & $\begin{array}{c}\text { Clavatula (Perrona) birmanica } \\
\text { VREDENBURG }\end{array}$ & 1921c, p. 85 \\
\hline $\begin{array}{l}P . \text { birmanica singuensis } \\
\text { VREDENBURG }\end{array}$ & $C .\left(P_{\dot{\text { VREDENBURG }}}\right.$ birmanica singuensis & 1921a, p. 278 \\
\hline Pusionella munga (NoETliNG) & C. (P.) munga NoEtling & 1901, p. 347 \\
\hline \multicolumn{3}{|l|}{ Turrinae } \\
\hline $\begin{array}{l}\text { Hemipleurotoma albinoides } \\
\text { (MARTIN) }\end{array}$ & $\begin{array}{c}\text { Pleurotoma albinoides MARTIN } \\
\text { var., VREDENBURG }\end{array}$ & 1921c, p. 97 \\
\hline$H$. bonneti CossmaNN & $\begin{array}{r}P . \text { (Hemipleurotoma) bonneti } \\
\text { COSSMANN, VREDENBURG }\end{array}$ & 1921c, p. 97 \\
\hline $\begin{array}{c}\text { Gemmula (Paragemmula) } \\
\text { thyrsus VREDENBURG }\end{array}$ & $\begin{array}{c}P .(G e m m u l a) \text { thyrsus } \\
\text { VREDENBURG* }\end{array}$ & 1921c, p. 103 \\
\hline Unedogemmula ickei (MARTIN) & P. ickei MARTIN, VREDENBURG & 1921c, p. 96 \\
\hline $\begin{array}{l}\text { Ptychosyrinx birmanicus } \\
\text { (VREDENBURG) }\end{array}$ & $P . \underset{\text { VREDENBURG* }}{(\text { Gemmula }) \text { birmanica }}$ & 1921c, p. 102 \\
\hline
\end{tabular}


(Continued from Table 1)

\begin{tabular}{|c|c|c|}
\hline revised name & original name & \\
\hline $\begin{array}{l}\text { Lophioturris fascialis } \\
\text { (LAMARCK) }\end{array}$ & $P . \underset{\text { VREDENBURG }}{\text { fascialis Lamarck, }}$ & 1921c, p. 96 \\
\hline $\begin{array}{c}\text { Xenuroturris (Reticuloturris) } \\
\text { iris (VREDENBURG) }\end{array}$ & $P . \underset{\text { VREDENBURG* }}{\text { Hemipleurotoma }}$ iris & 1921c, p. 98 \\
\hline $\begin{array}{l}\text { Turridrupa ? yenanensis } \\
\text { (NOETLNG) }\end{array}$ & P. yenanensis NoETLING & 1895 , p. 42 \\
\hline $\begin{array}{c}\text { Epalxis singuensis } \\
\text { (VREDENBURG) }\end{array}$ & $P . \underset{\text { VREDENBURG }}{\text { Hemipleurotoma }}$ singuensis & 1921c, p. 98 \\
\hline \multicolumn{3}{|l|}{ Borsoniinae } \\
\hline $\begin{array}{c}\text { Awateria ? dormitor } \\
\text { (VREDENBURG) }\end{array}$ & Drillia dormitor VREDENBURG* & 1921c, p. 110 \\
\hline$\underset{\text { (BROCCHI) }}{\text { Bathytoma cataphracta }}$ & $\begin{array}{l}\text { Bathytoma cataphracta } \\
\text { (BROCCHI), VREDENBURG }\end{array}$ & 1921c, p. 123 \\
\hline B. (subgen. nov. ?) herklotsi & $\begin{array}{l}B . \text { herklotsi MARTIN, } \\
\text { VREDENBURG }\end{array}$ & 1921c, p. 123 \\
\hline \multicolumn{3}{|l|}{ Clavinae } \\
\hline $\begin{array}{c}\text { Pleuropyramis quinquangularis } \\
\text { VREDENBURG }\end{array}$ & $\begin{array}{l}\text { Clathurella (Pleuropyramis) } \\
\text { quinquangularis } \\
\text { VREDENBURG* }\end{array}$ & 1921c, p. 124 \\
\hline $\begin{array}{l}\text { Inquisitor pinfoldi } \\
\text { (VREDENBURG) }\end{array}$ & $\underset{\text { VREDENBURG* }}{\text { Drillia }}$ (Brachytoma) pinfoldi & 1921c, p. 110 \\
\hline $\begin{array}{l}\text { I. molengraaffi pulcherrimus } \\
\text { (VREDENBURG) }\end{array}$ & D. pulcherrima VREDENBUR $\mathrm{A}^{*}$ & 1921c, p. 105 \\
\hline I. subbatavianus (VREDENBURG) & D. $\underset{\text { VREDENBURG }}{\text { (Crassispira) subbataviana }}$ & 1921 c, p. 118 \\
\hline $\begin{array}{l}\text { I. myaukmigonensis } \\
\text { (VREDENBURG) }\end{array}$ & D. $\underset{\text { VREDENBURG* }}{(C .) \text { myaukmigonensis }}$ & 1921c, p. 121 \\
\hline I. tjemoroensis (MARTIN) & $\begin{array}{l}\text { D. (Brachytoma) tjemoroensis } \\
\text { MARTIN var., VREDENBURG }\end{array}$ & 1921 b, p. 309 \\
\hline I. cotteri (VREDENBURG) & $\begin{array}{l}\text { D. protointerrupta NoETLING } \\
\text { (pars) }=D . \text { (Crassispira) } \\
\text { cotteri VREDENBURG }\end{array}$ & $\begin{array}{l}1901, \text { p. } 354 \\
1921 \text {, p. } 283\end{array}$ \\
\hline I. batavianus (MARTIN) & D. $\underset{\text { VREDENBURG }}{(C .) \text { bataviana MARTIN var., }}$ & $1921 \mathrm{c}$, p. 116 \\
\hline I. kamaensis (VREDENBURG) & $\begin{array}{c}\text { D. protointerrupta NOETLING } \\
\text { (pars) }=D . \text {. (Crassispira) } \\
\text { kamaensis VREDENBURG }\end{array}$ & $\begin{array}{l}1901, \text { p. } 354 \\
1921 b, \text { p. } 278\end{array}$ \\
\hline $\begin{array}{l}\text { I. (Ptychobela) annandale } i \\
\text { (VREDENBURG) }\end{array}$ & $\begin{array}{l}\text { D. (Brachytoma) annandalei } \\
\text { VREDENBURG* }\end{array}$ & 1921c, p. 114 \\
\hline Drillia saraswati VREDENBURG & D. (B.) saraswati VREDENBURG* & 1921c, p. 114 \\
\hline D. reticulata VREDENBURG & D. (B.) reticulata VREDENBURG* & $1921 \mathrm{c}$, p. 115 \\
\hline $\begin{array}{l}\text { Splendrillia indica } \\
\text { (VREDENBURG) }\end{array}$ & D. indica VREDENBURG* & 1921c, p. 107 \\
\hline $\begin{array}{c}\text { Crassispira (Crassispira) } \\
\text { gautama (VREDENBURG) }\end{array}$ & D. $\underset{\text { VREDENBURG* }}{\text { Brachytoma }}$ gautama & 1921c, p. 116 \\
\hline C. (C.) iravadica VREDENBURG & D. (Crassispira) iravadica & $1921 \mathrm{c}$, p. 121 \\
\hline $\begin{array}{c}\text { C. }(C .) \text { mindegyensis } \\
\text { VREDENBURG }\end{array}$ & $\begin{array}{l}\text { D. (C.) mindegyensis } \\
\text { VREDENBURG* }\end{array}$ & 1921c, p. 122 \\
\hline C. ? decemplicata VREDENBURG & D. $\underset{\text { VREDENBURG** }}{(C .)}$ decemplicata & 1921c, p. 109 \\
\hline C. $\underset{\text { VREDENBURG }}{(\text { Birmadrillia })}$ constricta & D. (C.) constricta VREDENQUR ** & 1921 c, p. 121 \\
\hline C. ? subpromensis VREDENBURG & D. $\underset{\text { VREDENBURG* }}{(C .) \text { subpromensis }}$ & 1921 c, p. 118 \\
\hline $\begin{array}{c}\text { Pulsarella? protocincta } \\
\text { (NoETLING) }\end{array}$ & D. protocincta NoETLING & 1901, p. 355 \\
\hline
\end{tabular}


(Continuem from Table 1)

\begin{tabular}{|c|c|c|}
\hline revised name & original name & \\
\hline $\begin{array}{l}\text { Conorbiinae } \\
\text { Genota ? singuensis } \\
\text { VREDENBURG }\end{array}$ & Genotia singuensis VREDENBURG* & 1921d, p. 132 \\
\hline \multicolumn{3}{|l|}{ Mangeliinae } \\
\hline $\begin{array}{l}\text { Pleurotomoides ? convexus } \\
\text { (VREDENBURG) }\end{array}$ & $\begin{array}{l}\text { Drillia (Brachytoma) convexa } \\
\text { VREDENBURG* }\end{array}$ & 1921c, p. 116 \\
\hline $\begin{array}{l}\text { Euclathurella (Miraclathurella) } \\
\text { tittabweensis } \\
\text { (VREDENBURG) }\end{array}$ & D. VREDENBURG* $^{\text {Crassispira) tittabweensis }}$ & $1921 \mathrm{c}$, p. 118 \\
\hline$\underset{\text { (VREDENBURG) }}{\left(M_{.}\right) \text {decemcostata }}$ & D. (C.) $_{\text {VREDENBURG* }}$ cotteri decemcostata & 1921c, p. 122 \\
\hline $\begin{array}{c}E .\left(M_{\text {(VREDENBURG) }} \text { elegantissima }\right. \\
\text { (VREN }\end{array}$ & $\begin{array}{l}\text { Mangilia elegantissima } \\
\text { VREDENBURG* }\end{array}$ & 1921c, p. 124 \\
\hline $\begin{array}{c}E .(M .) \text { dalabeensis } \\
\text { (VREDENBURG) }\end{array}$ & $\underset{\text { VREDENBURG* }}{\text { Drillia }}$ (Crassispira) dalabeensis & 1921c, p. 122 \\
\hline $\begin{array}{c}\text { Lioglyphostoma martini } \\
\text { (VREDENBURG) }\end{array}$ & Clathurella martini VREDENBURG* & 1921c, p. 124 \\
\hline $\begin{array}{c}\text { Cytharella ? birmanica } \\
\text { (VREDENBURG) }\end{array}$ & $\underset{\text { VREDENBURG }}{\text { Daphnella }}$ (Raphitoma) birmanica & 1921c, p. 126 \\
\hline
\end{tabular}

Species with asteriks were examined on the type specimens in the present study.

rhomoid in profile with sharp median angulation, which is crossed by vertical axial ribs. The second whorl becomes slightly rounded, but still holds peripheral angulation and it has a few secondary spiral threads above and below the angulation. Axials gradually becomes lightly curved in antisigmoidal fashion. The third and later whorls lose peripheral angulation and spiral sculpture. Suture is wavy by axial ribs. Base is slightly contracted.

The juvenile part of the present specimen conforms with the characteristics of Leiocithara HEDLEY, 1922, but the later part is similar to Cytharella MoNTERoSATo, 1875, although the aperture is not observable. The present species is tentatively included in Cytharella. It may suggest the phylogenetic relation of Cytharella and Leiocithara, which respectively appear in the Miocene and Pleistocene.

\section{Tertiary biostratigraphy of the Burmese turrids}

Neogene molluscan fanunas of Burma was first dealt by NoETLING (1895) on the material collected by himself mainly in the Yenangyat and Minbu areas and then the second monograph was published in 1901 dealing with the fossil material from the Singu and Kama areas, respectively collected by himself and ThEobaLD. On that occasion he recognized several "zones". Later VREDENBURG revised the NoETLING's monographs (1921 a) and zones (1921 b) on the foundation of the newly obtained fossils from the south area of Minbu together with the accumulated field data by several workers as THEOBALD, CotTER, RAo, etc. He divided then the Tertiary from the Eocene to the Miocene into the Pondaung, Yaw, Shwezetaw, Sitsayan, Singu, Kama and Pyalo Stages in ascending order, which he tenetatively correlated to the European standard stages from the Up- 
per Eocene to the Burdigalian respectively. While petroleum geologists in Burma proposed a quite different biostratigraphic scheme independent of the GSI scheme on the basis of both surface and subsurface data. Standard stages of the Tertiary from the Middle Eocene to the Upper Miocene are, according to them, the Pondaung, Yaw, Schwezetaw, Padaung, Okhmintaung, Pyawbwe, Kyaukkok and Obogon in ascending order. EAMES (1950 and 1970) and EAMES and SAVAGE (1975) claimed that the Burmese stages are respectively correlative to the European stages by means of mollusks, echinoids and foraminifers. Therefore the standard stages of the Burmese Tertiary seem to give a suitable basis for an interregional correlation. However, there is a difficult problem that correlation between the GSI stages and the petroleum geologists' stages has not necessarily be settled, although the type areas of the stages of both schemes are not far separated geographically from each other. For instance, the "type localities" (sections ?) of the Miocene stages are, according to U AUNG and U KYAW (1966), selected respectively in the west wing of the Linke syncline, southwest of $\mathrm{Minbu}$, i.e. Pyawbwe village $\left(20^{\circ} 01^{\prime} \mathrm{N}, 94^{\circ} 38^{\prime} \mathrm{E}\right)$ for the Pyawbwe Stage, Kyaukkok village $\left(19^{\circ} 54^{\prime} \mathrm{N}, 94^{\circ} 43^{\prime} \mathrm{E}\right)$ for the Kyaukkok Stage and Obogon village $\left(19^{\circ} 58^{\prime} \mathrm{N}, 94^{\circ} 8^{\prime} \mathrm{E}^{*}\right)$ for the Obogon Stage. While VREDENBURG's Miocene fossil localities are scattered in the area from Prome northward to Dalabe, which is situated about fifty kilometers south of Minbu. In consequence of insufficient correlation, biostratigraphic evaluation of some of the fossil localities has not been concluded, at least, in the publications. Under the situation mentioned above, I am inclined to adopt an approximate correlation of the two sets of biostratigraphical units as shown below.

$\begin{array}{ll}\text { Pyalo -Obogon } & \text { Upper Miocene } \\ \text { Kama -Kyaukkok } & \text { Middle Miocene } \\ \text { Singu - Pyawbwe } & \text { Lower Miocene } \\ \text { Sitsaya-Okhmintaung } & \text { Upper Oligocene }\end{array}$

Concerning the stratigraphic ranges of species, I follow EAMES and SAvAGE (1975).

According to them the first appearance of Inquisitor cotteri (VREDENBURG) together with six other molluscan species indicates the boundary between the Pyawbwe and the overlaying Kyaukkok stage, i.e. EAmes' "Datum A" (1970). Occurrence of Paradrillia ermelingi (MARTIN), Hemipleurotoma bonneti CossmanN, Unedogemmula ickei (MARTIN) and Pulsarella ? protocincta (VREDENBURG) is limited to the Kyaukkok Stage. Species with geologic range from the Kyaukkok to the Obogon Stage are Turricula buddhaica (VREDENBURG), T. navarchus thangaensis (VREDENBURG), Pleurofusia feddeni iravadica VREDENBURG, $P$. (Neopleurofusia) scala VREDENBURG, Inquisitor tjemoroensis (MARTIN), I. (Ptychobela) annandalei (VREDENBURG), Splendrillia indica (VREDENBURG), Crassispira promensis (NoETLING), Pleuropyramis quinquangularis VREDENBURG, Euclathurella (Miraclathurella) tittabweensis (VREDENBURG) and Euclathurella (Miraclathurella) dalabeensis (VREDENBURG).

* probably misprint for $38^{\prime} \mathrm{E}$ or $48^{\prime} \mathrm{E}$ 
Table 2. Turrid species occurring in common in the Burmese and Indonesian Tertiary

\begin{tabular}{lll}
\hline Paradrillia ermelingi (MARTIN) & Ky-Ob & Mio. \\
Unedogemmula ickei (MARTIN) & Ky-Ob & Re-Od \\
Hemipleurotoma albinoides (MARTIN) & Ob & Pr-Od \\
Bathytoma (n. subgen.) herklotsi MARTIN & Kama & Od \\
Inquisitor cotteri (VREDENBURG) & Ky & Re \\
I. tjemoroensis (MARTIN) & Ky-Ob & Od \\
I. batavianus (MARTIN) & Kama & Od \\
Crassispira mindegyiensis VREDENBURG & Singu & Mid. Mio. \\
\hline
\end{tabular}

Ky: Kyaukkok Middle Miocene, Ob: Obogon Upper Miocene, Kama: mainly Middle Miocene, Singu: mainly Lower Miocene, Re: Rembangian lower Middle Miocene, Pr: Preangerian upper Middle Miocene, Od: TjiOdengian Upper Miocene.

Table 3. Close allies occurring in the Burmese and Indonesian Tertiary

Corresponding taxa are tabulated in a pair, B (Burma) and I (Indonesia)

\begin{tabular}{lll}
\hline B & Pleurofusia feddeni iravadica VRED. & Ky-Ob \\
I P. sedanensis (HAANSTRA et SPIKER) & Re \\
B Pleurofusia (Pseudofusia) yabei (VRED.) & Ob \\
I P. (P.) dinglensis SHUTo & Upmost Mio. \\
B Turricula (Nangulanica) birmanica (VRED.) & Kama \\
I $T$. (N.) hillegondae (MARTIN) & Mid. Eo. \\
B Nihonia ? birmanica (VRED.) & Mio. \\
I N. witkampi BEETS & Up. Mid. Mio. \\
B Cosmasyrinx sucabumianus karenaicus (NOET.) & Kama \\
I C. sucabumianus (MARTIN) & Re \\
B Xenuroturris (Reticuloturris) iris (VRED.) & Ky-Ob \\
I X. (R.) sumatrana (HAANSTRA et SPIKER) & Od \\
B Perrona birmanica VRED. & Ob \\
I P. erbi HAANSTRA et SPIKER & Od \\
B Inquisitor pindoldi (VRED.) & Singu \\
I I. durgae BEETS & Od \\
B I. molengraaff pulcherrinus (VRED.) & Ky-Ob \\
I I. molengraaff molengraaff (MARTIN) & Progo \\
B I. (Ptychobela) annandalei (VRED.) & Ky-Ob \\
I I. (P.) pamotanensis (MARTIN) & Re \\
B Crassispira (Birmadrillia) constricta VRED. & Ob \\
I C. (B.) palembangensis (HAANSTRA et SPIKER) & Od \\
B Eosurcula garrowi (VRED.) & Yaw \\
I E. denigeri (MARTIN) & Mid. Eo. \\
\hline
\end{tabular}

Yaw $=$ Middle Eocene, Progo $=$ Lower Miocene.

Other abbreviations, see Table 2.

Pleurofusia yabei (VREDENBURG), P. phasma (VREDenburg), Xenuroturris (Reticuloturris) iris (VREDENBURG), Hemipleurotoma albinoides (MARTIN), Gemmula (Paragemmula) thyrsus VREDENBURG, Drillia saraswati VREDENBURG, Crassispira ? decemplicata VREDENBURG, C. (Birmadrillia) constricta VREDENBURG and Inquisitor molengraafi pulcherrimus (VREDENBURG) are limited to the 
Obogon Stage. Turricula promensis (VREDENBURG) has been known from the Obogon Stage in Burma but may range to the Kyaukkok Stage, because it has been known from the Middle Miocene of Assam. The above facts seem to verify a biostratigraphic value of turrids in the Burmese Tertiary, particularly in the Neogene.

Eight species out of 64 turrids hitherto reported from the Burmese Tertiary occur in common both in Burma and Indonesia (Table 2). Another nine species from the Burmese Tertiary respectively have their close ally in Indonesian Tertiary fauna as indicated in Table 3. Species of common occurrence reveal a fairly good correspondance between the two regions as regard to their geologic ranges. That is to say, they prove a correlation of the Kyaukkok Stage to the Rembangian and the Obogon to the Tjiodengian. It is, however, not necessarily clear whether or not the Preangerian of Indonesia is included in the upper half of the Kyaukkok, because the precise lithostratigraphic data of the Burmese Tertiary are not available.

\section{References}

ADAMS, H. and A. ADAMS (1853): The genera of recent Mollusca; arranged according to their organization, Vol. 1 (part), 1-256, London.

Bartsch, P. and H. A. REhder (1939): New turrid mollusks from Florida. Proc. U. S. Nat. Mus., 87, (3070), 127-138.

BeETs, C. (1941) : Eine jungmiocäne Mollusken fauna von der Halbinsel Mangkalihat, Ost-Borneo. Verh. Geol. Mijnb. Genoot. Ned. Kol. Geol. Ser., 13, (1), 1-218, Taf. 1-8.

(1983): Preangerian (Miocene) Mollusca from the lower Songkulirang Marl Formation, Kari Orang, Kalimantan (East Boreno). Scripta Geol., 67 49-66, pl. 4.

Bellard, L. (1877): I molluschi dei terreni terziari de piemonte e della Liguria; Parte II. 1-364, Tav. 1-9, (Mem. Reale Acad. Sci. Torino, Ser. 2, 29).

Brown, H. G. (1831): Italiens Tertiär-Gebirge und deren Einschlüsse. Heidelberg. (non vidi)

CASEY, T. L. (1904) : Notes on the Pleurotomidae with descriptions of some new genera and species. Trans. Acad. Sci. St. Louis, 14 (5), 123-170.

Cossmann, M. (1889): Catalogue illustré des coquilles fossiles de l'Eocéne des environs de Paris. IV. Ann. Soc. Roy. Malacol. Belg., 24, (4), 3-381, pl. 1-12. (1900) : Faune Pliocénique de Karikal. Journ. de Conchyl. 48, 14-66, pl. 2-4. (1906): Essais de paléoconchologie comparée, 7, annexe, 217-224, pl. 14. Paris. et A. Peyrot (1931): Conchologie néogénique de l'Aquitaine. Scaphopodes et Gastropodes (partie). Actes Soc. Linn. Bordeaux, 83, 5-116, pls. 4-6.

DALL, W. H. (1889): Reports of the results of dredging, under the supervision of Alexander Agassie, in the Gulf of Mexico and in the Carribean Sea by the U. S. Coast Survey steamer "Blake". Bull. Mus. Comp. Zool., 18, 1-492, pl. 10-40.

DEY, A. K. (1962): The Mollusca from Quilon, Kerala (India). Palaeont. Indica, N. S., 36, 1-129, pl. 1-10.

Eames, F. E. (1950): The Pegu System of Burma. Rec. Geol. Surv. India, 81 (2), $377-388$.

(1970): Some thoughts on the Neogene/Palaeogene boundary. Palaeogeogr., Palaeoclimato., Palaeoecol., 8, 37-48.

and R. J. G. SAVAGE (1975): Tertiary Faunas (revised ed.), Vol. 2, 1-447, London. 
Erünal-Erentöz, L. (1958): Mollusques du Néogéne des basins de Karaman, Adana et Hatay (Turquie). Publ. Inst. d'Études Recher. Min. Turquie, Ser. C. (4), 1-232, pl. 1-36.

Fischer, P. J. (1927) : Beitrag zur Kenntnis der Pliozän fauna der Mollukken Inseln Seran und Obi. Paläont. v. Timor, Lief. 15, 1-179, Taf. 212-217.

GABb, W. M. (1873) : Descriptions of some new genera of Mollusca. Proc. Acad. Nat. Sci. Philadelphia, 24, 270-274.

GraY, J. E. (1838): On some new species of quadrupeds and shells. Ann. Mag. Nat. Hist., 1, 27-30.

(1847) : A list of genera of recent mollusca, their synonyma and types. Proc. Zool. Soc. London, 15, 129-219.

Gregorio, A. de (1890): Monographie de la faune Eocéne de l'Alabama. Ann. Géol. Paléont. 7 et 8. Palermo (non vidi)

HaAnstra, U. and E. SPIKer (1932a): Ueber Fossilien aus dem Altmiozän von Rembang (Nord Java). Proc. Konink. Akad. Wetensch. Amsterdam, 35 (8), 1095$1103,1 \mathrm{pl}$.

(1932b): Ueber jungneogene Molluskenfauna aus den Residenzen Benkoelen und Palembang, S. W. Sumatra. ibid., 35, (9), 1313-1324, 1 pl.

Hertlein, L. G. and A. M. Strong (1951): Mollusks from the West Coast of Mexico and Central America Pt. X. Zoologica (New York) 36, (2), 67-120, pls. 1-11.

HedLeY, C. (1918): Check list of the marine fauna of New South wales. Jour. Roy. Soc. N. S. W., 51, Suppl. M. 1-220.

- (1922): A revision of the Australian Turridae. Rec. Austr. Mus., 13, (6), $213-359$, pl. $42-56$.

Koenen, A. von (1890): Norddeutsche Unter-Oligocän und seine Mollusken-Fauna. 4, Conidae, Voltidae und Cypraeidae. Abh. Geol. Specialkarte Preuss. Thuring. Sta., 10, (2), 281-570, Taf. 24-39.

Laseron, C. F. (1954): The New South Wales Turridae. Roy. Zool. Soc. N. S. W. Handb., 1-56, pl. 1-12.

MacNeIL, F. S. (1960): Tertiary and Quaternary Gastropods of Okinawa. U. S. Geol Surv. Prof. Pap. (339), 1-148, pl. 1-19.

MakiYama, J. (1940): Nomenclatural notes on some genera of Turridae. Trans. Palaeont. Soc. Japan., (102), 25-26.

Martens, F. von (1903): Die beschalten Gastropoden der deutschen Tiefsee-Expedition, 1898-1899. A Systematisch-geographischer Teil. Wisseusch. Ergebn. Deutsch. Tiefsee-Exped., 7, 3-146, Taf. 1-5.

Martin, K. (1895-1906): Die Fossilien von Java. Samml. Geol. Reichsmus, Leiden, N. F., 1, (1), 1-325, Taf. 1-45.

- (1914-15) : Die Fauna des Obereocäns von Nanggulan, auf Java. A. Gastropoda. ibid. N. F., 2, 107-222, Taf. 1-8.

(1916) : Die altmiocäne Fauna des West-Progogebirges auf Java. ibid. N. F., 2, 223-261, Taf. 1-3.

Marwick, J. (1931): The Tertiary Mollusca of the Gisborne district. N. Z. Geol. Surv. Paleont. Bull. (13), 1-177, pl. 1-18.

Melvill, J. C. (1923) : Descriptions of twenty-one species of Turridae (Pleurotomidae) from various localities in the collection of Mr. E. R. Sykes. Proc. Malac. Soc. London, 15, 162-171, pl. 4-5.

(1927): Descriptions of eight new species of the family Turridae and of a new species of Mitra. ibid., 17, 149-155, pl. 12.

and R. Standen (1903): Descriptions of sixty-eight new Gastropoda from the Persian Gulf, Gulf of Oman, and North Arabian Sea, dredged by Mr. F. W. TownSEND, of the Indo-European Telegraph Service, 1901-1903. Ann. Mag. Nat. Hist. Ser. 7, 12, 289-324, pl. 20-23.

Monterosato, T. A. di (1875): Note intorno ad alcuni articole di conchiologia mediterranea pubblicati nel jahrbücher der deutschen malakozoologischen Geselschat 
dal signor H. C. Weinkauff e dal Dott. Kobelt. Bull. Soc. Malac. Ital., 1, (1), 68-73.

NoEtLing, F. (1895): On some marine fossils from the Miocene of Upper Burma. Mem. Geol. Surv. India., 27, (1), 1-45, pl. 1-10.

(1901): Fauna of the Miocene beds of Burma. Palaeont. Indica, N. S., 1, (3), 1-378, pl. 1-25.

Powell, A. W. B. (1942): The New Zealand Recent and fossil Mollusca of the Family Turridae with general notes on turrid nomenclature and systematics. Bull. Auckland Inst. Mus., (2), 1-192, pl. 1-14.

(1964): The Family Turridae in the Indo-Pacific. Pt. 1. The subfamily Turrinae. Indo-Pacific Moll., 1, (5), 227-345, pl. 172-262.

(1969): ibid. Pt. 2. The subfamily Turriculinae. ibid., 2, (10), 207-415, pl. $188-323$.

SCHUMACHER, C. F. (1817): Essai d'un nouveau systéme des habitations des vers testaces. 1-287, 22 pls. Copenhague.

Shuto, T. (1969): Neogene gastropods from Panay Island, the Philippines. Mem. Fac. Sci., Kyushu Univ., Ser. D, Geol., 19, (1), 1-250, pl. 1-24.

(1980): A note on the Eocene turrids of the Nangulan Formation, Java. Prof. S. Kanno Memorial Volume, 25-52, pl. 3-5.

(1983): New turrid taxa from the Australian Waters. Mem. Fac. Sci., Kyushu Univ., Ser. D, Geol., 25, (1), 1-26, pl. 1-2.

Suter, H. (1917) : Descriptions of new Tertiary Mollusca occurring in New Zealand, accompanied by a few notes on necessary changes on nomenclature. New Zealand Geol. Surv. Paleont. Bull. (5), 1-93, pl. 1-13.

Swainson, W. (1840): Treatise on Malacology, 1-419. London.

ThIELE, J. (1925) : Gastropoda II. Wissensch. Ergebn. Deutsch. Tiefsee-Exped., 17, 1-348, Taf. 1-34.

U AUNG Khin and U KYAW Win (1966): Geology and hydrocarbon prospects of the Burma Tertiary geosyncline. Union of Burma Jour. Sci. Tech. for 1966, 53-73, 3 maps.

VoKes, H. F. (1939): Molluscan faunas of the Domengine and Arroyo Hondo formations of the California Eocene. Ann. New York Acad. Sci., 38, 1-246, pl. 1-22.

VREDENBURG, E. (1921a) : Results of a rivision of some portions of Dr. NoETLING's second monograph of the Tertiary fauna of Burma. Rec. Geol. Surv. India, 51, (3), 224-302.

(1921b) : Note on the marine fossils collected by Mr. Pinfold in the Garo Hills. ibid., 51, (3), 303-337, pl. 8-9. (1921c): Comparative diagnoses of Pleurotomidae from the Tertiary formations of Burma. ibid., 53, (2), 83-129, pl. 12-14.

(1921d): Comparative diagnoses of Conidae and Cancellariidae from the Tertiary formations of Burma. ibid., 53, (2), 130-141, pl. 15.

Woodring, W. P. (1928) : Miocene molluses from Boden, Jamaica. Pt. 2. Publ. Carnegie Inst. Washington, (385), 1-459, pl. 1-40. 